\title{
The Rio de la Plata craton and the adjoining Pan-African/brasiliano terranes: Their origins and incorporation into south-west Gondwana ${ }^{\star}$
}

\author{
Carlos W. Rapela ${ }^{\mathrm{a}, *}$, C. Mark Fanning ${ }^{\mathrm{b}}$, Cesar Casquet ${ }^{\mathrm{c}}$, Robert J. Pankhurst ${ }^{\text {a }}$, Luis Spalletti ${ }^{\mathrm{a}}$, \\ Daniel Poiré ${ }^{\mathrm{a}}$, Edgardo G. Baldo ${ }^{\mathrm{e}}$ \\ a Centro de Investigaciones Geologicas (CONICET-UNLP), 1900 La Plata, Argentina \\ b Research School of Earth Sciences, The Australian National University, Canberra, Australia \\ ${ }^{c}$ Departamento de Petrología y Geoquímic (Universidad Complutense), Instituto de Geociencias (CSIC, UCM), 28040 Madrid, Spain \\ d Visiting Research Associnte, British Geological Survey, Keyworth, Nottingham NG12 5GG, United Kingdom \\ - CICTERRA (CONICET-UNC), 5000 Córdoba, Aigentin
}

Keywords:

Palaeoproterozoic

Cratons

$\mathrm{U}-\mathrm{Pb}$ provenance

Neoproterozoic rifting

Southwestern Gondwana assembly

\begin{abstract}
A B S T R A C T
The Neoproterozoic to Early Cambrian amalgamation of SW Gondwana through the Brasiliano/Pan-African orogeny is reviewed with emphasis on the role of the Río de la Plata craton of South America in the light of new evidence from a borehole at the eastern end of the Tandilia belt $\left(38^{\circ} \mathrm{S}\right)$. $\mathrm{U}-\mathrm{Pb}$, Hf and $\mathrm{O}$ isotope data on zircon indicate that this un-reworked Palaeoproterozoic craton abuts against a distinct continental terrane to the east (Mar del Plata terrane). The craton is bounded everywhere by transcurrent faults and there is no evidence to relate it to the Neoproterozoic mobile belts now seen on either side. The Punta Mogotes Formation at the bottom of the borehole contains $740-840 \mathrm{Ma}$ detrital zircons that are assigned to a widespread Neoproterozoic rifting event. The data suggest that the Mar del Plata terrane rifted away from the southwestern corner of the Angola block at c. $780 \mathrm{Ma}$. Negative $\varepsilon \mathrm{Hf}_{\mathrm{t}}$ values and $\boldsymbol{6}^{18} \mathrm{O}>6.5 \%$ o suggest derivation by melting of old crust during a protracted extensional episode. Other continental terranes may have formed in a similar way in Uruguay (Nico Pérez) and southeastern Brazil, where the Schist Belt of the Dom Feliciano orogenic belt is probably a correlative of the Punta Mogotes sequence, implying that the Dom Feliciano belt must extend at least as far as $38^{\circ} \mathrm{S}$. A new geodynamic scenario for West Gondwana assembly includes at least two major oblique collisional orogenies: Kaoko-Dom Feliciano (580-680 Ma) and Gariep-Saldania (480$580 \mathrm{Ma}$ ), the latter resulting from oblique impingement of the Rio de la Plata craton against the Kalahari craton. Assembly of this part of South-West Gondwana was accomplished before the Ordovician (to Silurian?) siliciclastic platform sediments of the Balcarce Formation in the Tandilia Belt covered the southern sector of Río de la Plata craton.
\end{abstract}

\section{Contents}

1. Introduction .

2. Geology .

2.1. The Río de la Plata craton and its boundaries

2.2. Tandilia belt and the Punta Mogotes borehole

3. Geochronological and isotopic results.

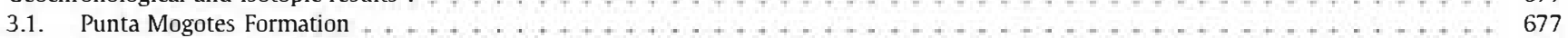

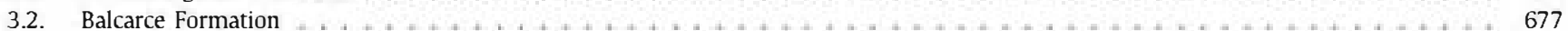

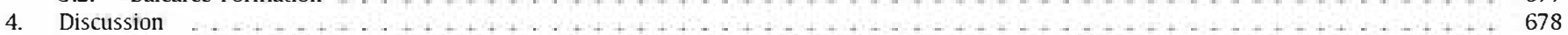

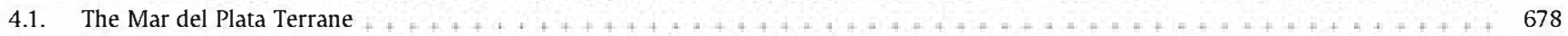

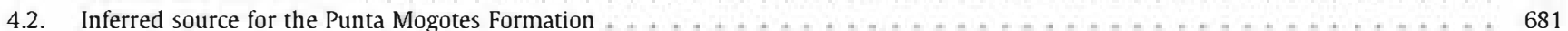

4.3. Relationship to the Dom Feliciano belt $\ldots+\ldots+\ldots+\ldots+\ldots \ldots+\ldots+\ldots+\ldots \ldots$

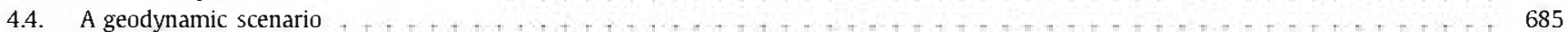




\section{Introduction}

The multi-phase Brasiliano/Pan-African African orogeny led to amalgamation of SW Gondwana in Neoproterozoic to Early Cambrian times. The details of this complex process involving closure of the intervening Adamastor Ocean (Hartnady et al., 1985), especially the timing of events and the role played by neighboring cratons, remain a matter of intense debate. This is notably the case for the Rio de la Plata craton, which has been a cornerstone in all palaeogeographical models of SW Gondwana amalgamation (e.g., Dalziel, 1997; Cawood and Buchan, 2007; Li et al., 2008; Chernicoff et al., 2011; Font et al., 2011; Tohver et al., 2011). This craton is the focus of this paper, with the aim of fixing its boundaries and adding new constraints on its role during the formation of SW Gondwana and its place in the overall Brasiliano/Pan-African orogeny.

The starting point is the information gathered from drill core samples from close to the present Atlantic coast, at the tip of the Tandilia belt on the inferred eastern margin of the Río de la Plata craton at $38^{\circ} \mathrm{SL}$. U-Pb SHRIMP detrital zircon age patterns and targeted Hf and oxygen isotopic analyse by I.A-ICP-MS and SHRIMP, respectively, were obtained for these critically-located sedimentary and meta-sedimentary samples.

Together with previous work, the new results allow us: (i) to propose a new eastern boundary for the Río de la Plata craton as a hidden fault that separates the craton from a distinct continental block that we call here the Mar del Plata Terrane, (ii) to state that this terrane is the southernmost extension of the Dom Feliciano Belt, (iii) to infer that the Mar del Plata Terrane was part of the southwestern Angola block following the break-up of Rodinia at c. $780 \mathrm{Ma}$ and became displaced during the Dom Feliciano-Kaoko orogeny (a similar origin is also inferred for other terranes within the Dom Feliciano belt, including those composed of old basement reworked in the Brasiliano orogeny, such as the Nico Pérez terrane in Uruguay), (iv) to recognize that the Río de la Plata that was not affected by the overall Brasiliano/Pan-African orogeny and that it is bounded on all sides by transcurrent faults of Late Neoproterozoic and Cambrian age, implying that the craton was allochthonous and that it reached its present position late during the assembly of SW Gondwana, (v) to propose a revised geodynamic model for this region for the period between the c. 780 rifting of the Angola Block and Kalahari cratons and 540-520 Ma when SW Gondwana was finally assembled, distinguishing between an older Dom FelicianoKaoko orogeny and a younger Gariep-Saldania orogeny within the overall Brasiliano/Pan-African orogeny.

\section{Geology}

\subsection{The Río de la Plata craton and its boundaries}

The Río de la Plata craton is the oldest and southernmost core of South America and is a key piece in the cratonic assemblage of SW Gondwana (Fig. 1). It is mostly covered by a thick pile of younger sediments, beneath which its true extent is largely inferred. However, geophysical and deep bore-hole geochronological studies indicate that the western edge of the craton is in sharp contact with the Early Palaeozoic Eastern Sierras Pampeanas (Booker et al., 2004; Rapela et al., 2007). This contact, here equated with the Córdoba Fault,

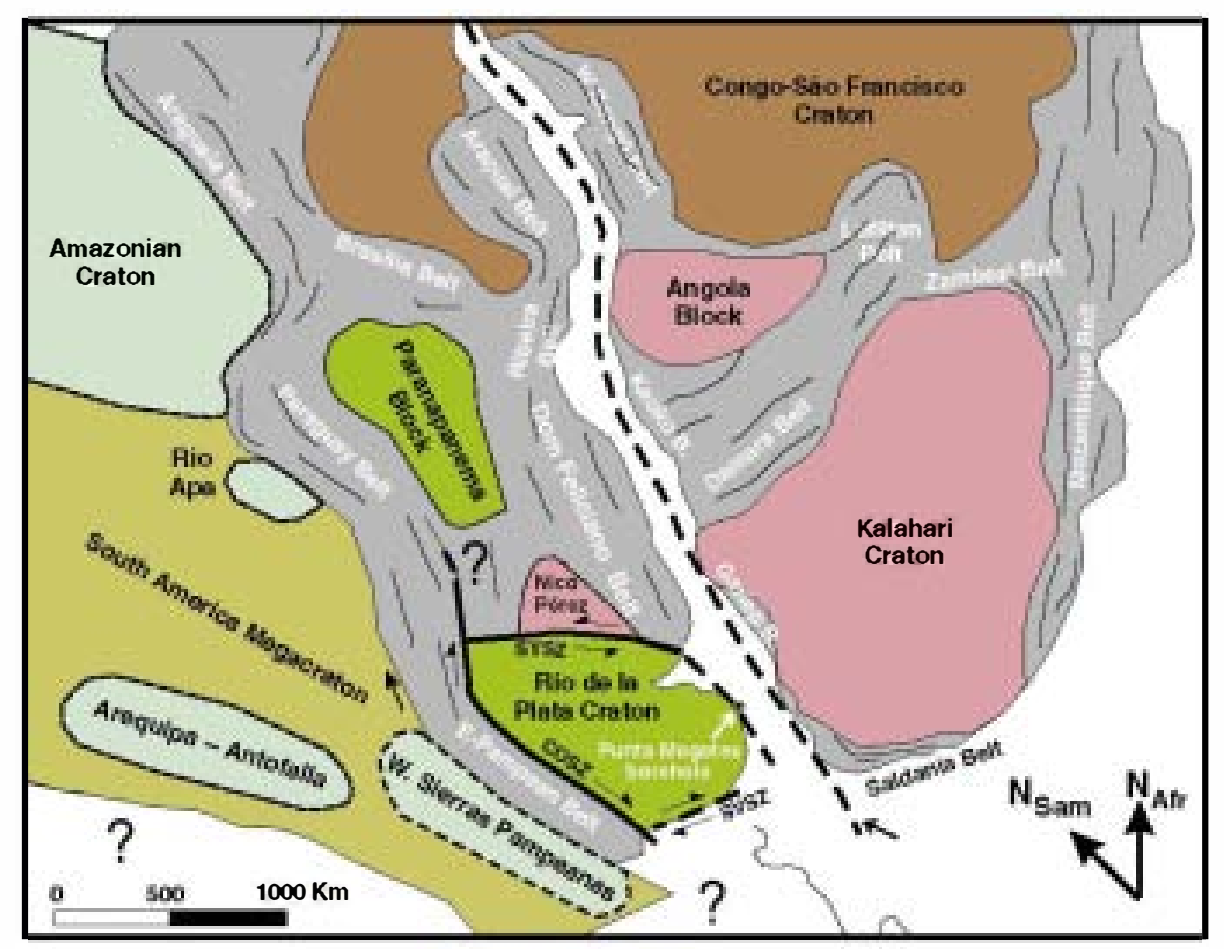

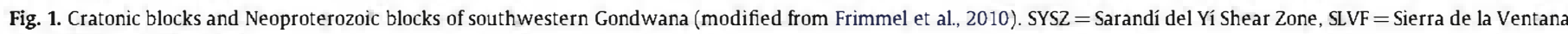
fault, $\mathrm{CORF}=$ Córdoba fault 
developed with dextral shearing, mostly during the Early (538528 Ma, Iannizzotto, 2010) to Iate Cambrian (Verdecchia et. al., 2011). The only exposed boundary is in central Uruguay (Fig. 2), where the Sarandi del Yi megashear (SYSZ) separates its Palaeoproterozoic basement unaffected by Neoproterozoic events (known here as the Piedra Alta terrane) from (a) the complex Archaean to Mesoproterozoic Nico Pérez terrane, reworked during the Neoproterozoic (Bossi and Cingolani, 2009; Oyhantçabal et al., 2009, 2010a and references therein), and (b) the Brasiliano/Pan-African Dom Feliciano belt (Oyhantçabal et al., 2010a) (Fig. 3a). The Dom Feliciano belt includes the following sequences: (i) basement inliers of Archaean to Mesoproterozoic ages, (ii) the Schist Belt, composed of pre-collisional Neoproterozoic metavolcanic and metasedimentary sequences at greenschist-to-lower amphibolite grade and (iii) the Granite Belt, of mainly Neoproterozoic calc-alkaline granitoids (Fig. 3a).

Rapela et al. (2007) included within the Río de la Plata craton (a) 2.26-2.05 Ga Palaeoproterozoic sequences unaffected by Neoproterozoic magmatism and metamorphic overprint (the Piedra Alta terrane, the Tandilia belt and basement reached in boreholes at the western edge of the craton), and (b) Archaean to Mesoproterozoic sequences affected by Neoproterozoic magmatism and metamorphic overprint (the Nico Pérez terrane and associated Rivera and Tacuarembó blocks, see yellow dashed line in Figs. 2, 3a). Fig. 4 shows a summary of the basement lithology and chronostratigraphy of these entities.

Recent geochronological, isotopic and geophysical evidence suggests that the Nico Pérez terrane and associated blocks were not part of the Río de la Plata craton and that they were probably juxtaposed during the Neoproterozoic (Oyhantçabal et al., 2010a). In this case the SYSZ should be regarded as the eastern margin of the craton against both the Nico Pérez terrane and the Dom Feliciano belt (Fig. 2, black dashed line, see also Fig. 3a). Evidence presented in this paper is consistent with this proposition and further refines the proposed limits of the craton (Fig. 2, red dashed line, see below).

\subsection{Tandilia belt and the Punta Mogotes borehole}

The Tandilia belt, located $300 \mathrm{~km}$ south of Buenos Aires (Figs. 1, 3b), is a northwest-southeast trending belt that includes the southernmost exposures of the Río de la Plata craton. The basement of the Tandilia belt is a Palaeoproterozoic complex of 2.26-2.07 tonalitic to granitic gneisses, amphibolites and migmatites, thick mylonites and a 1.59 tholeiitic dyke swarm (e.g., Hartmann et al., 2002b; Pankhurst et al., 2003; Cingolani et al., 2005, 2010). The Palaeoproterozoic basement is covered by (i) a Neoproterozoic carbonate-siliciclastic succession represented by the Sierras Bayas Group and the Cerro Negro Formation (Poiré and Spalletti, 2005, and references therein), and (ii) a Lower Palaeozoic succession of quartz-arenites, kaolinite-rich mud rocks, wackes, conglomerates and basal diamictites represented by the Balcarce Formation (Zimmermann and Spalletti, 2009; Van Staden et al., 2010, and references therein).

Detrital zircon ages provide important constraints on the age and probable sources of the Neoproterozoic and Early Palaeozoic

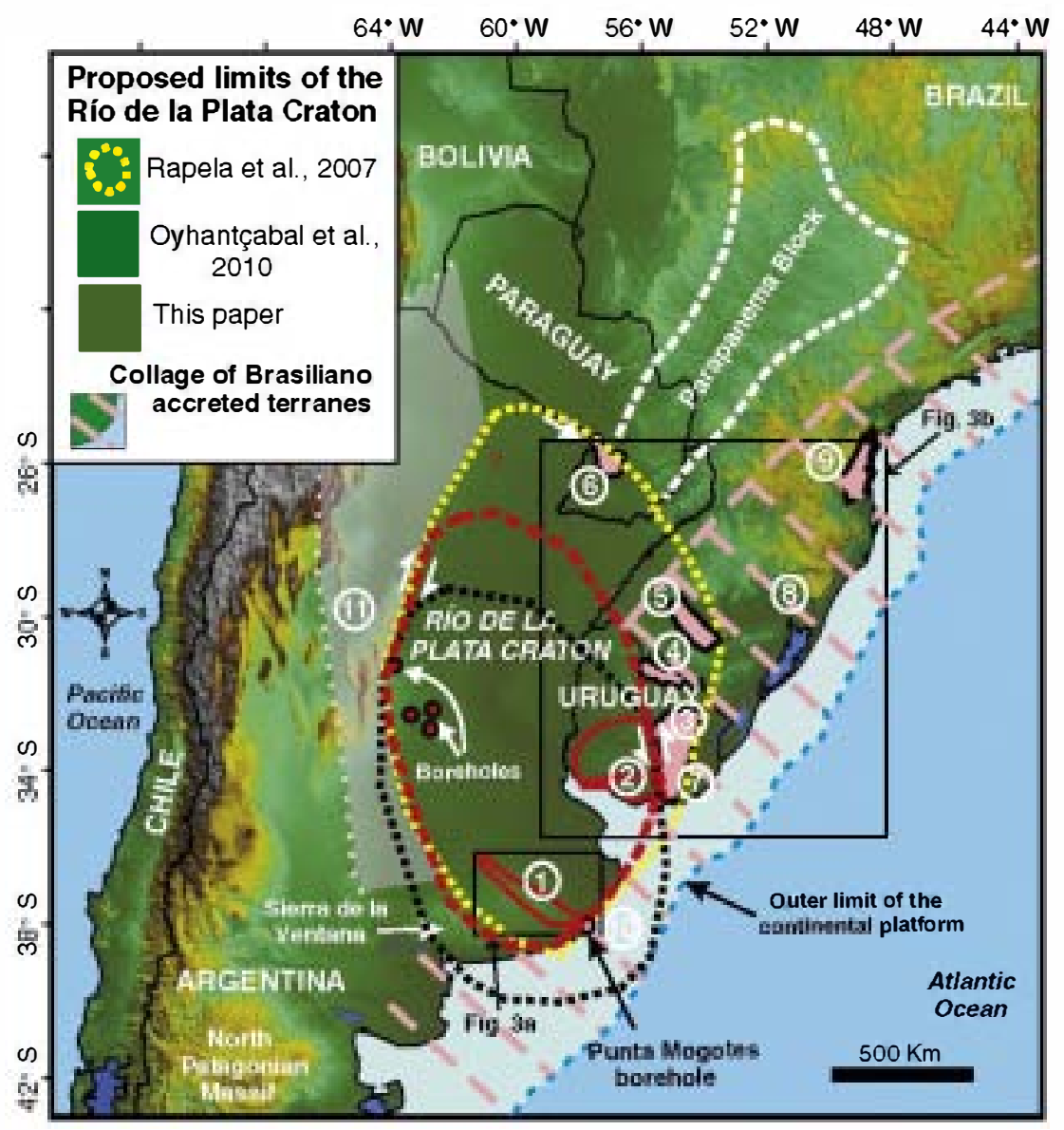

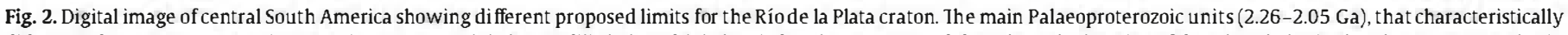

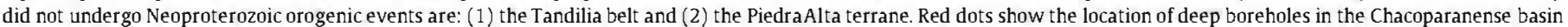

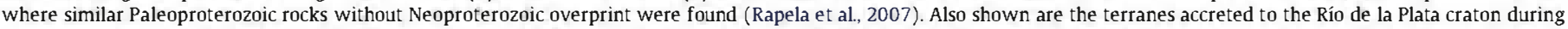

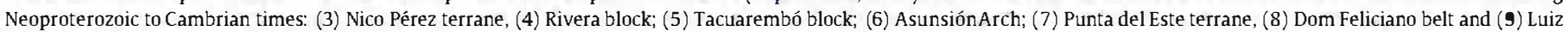
Alves block (see details in Fig. 3). 


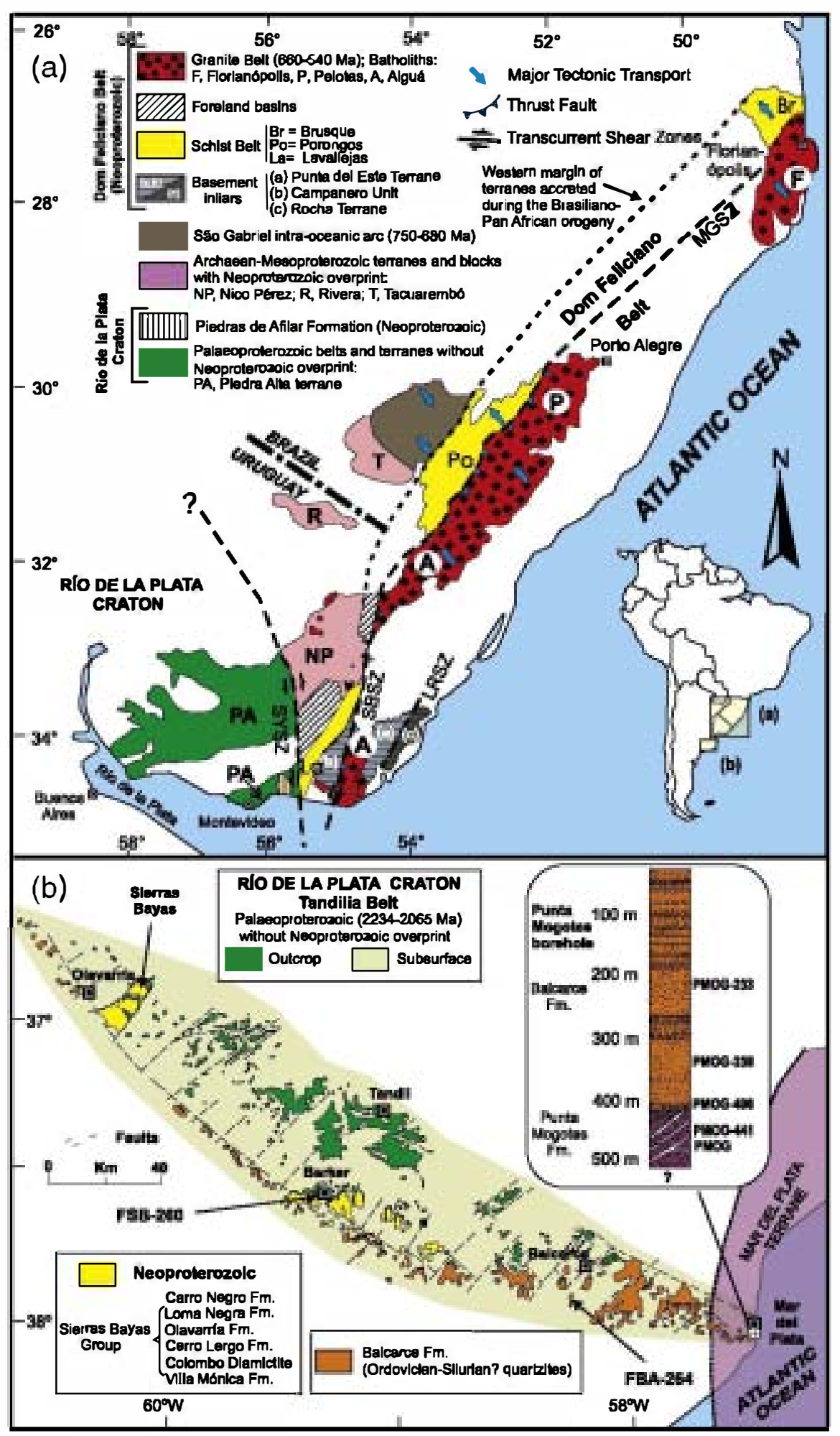

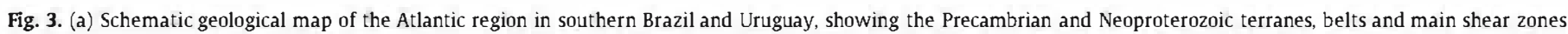

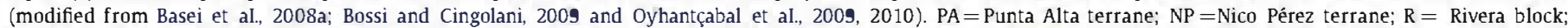

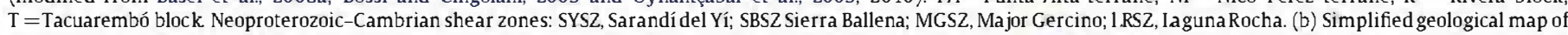

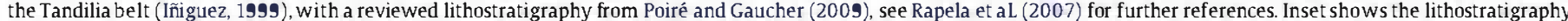

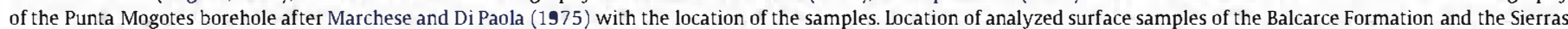

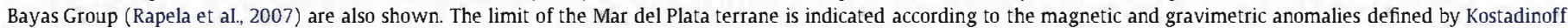
(1995).

successions. The zircon pattern of the Villa Mónica Formation, the lowermost unit of the Sierras Bayas Group in the areas of Barker and Olavarría (Fig. 3b), shows ages strongly concentrated around
$2200 \mathrm{Ma}$, indicating that the siliciclastic sequence is mostly derived from the underlying, locally exposed, basement of the craton (Rapela et al., 2007; Gaucher et al., 2008). On the other hand, the age pattern 


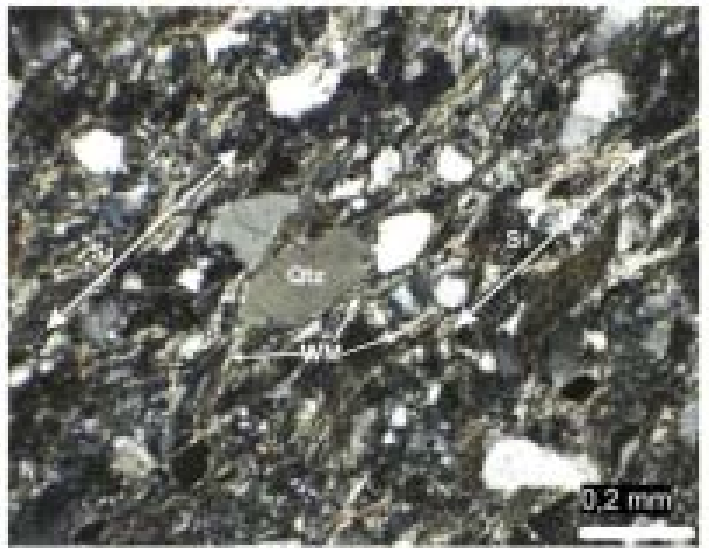

Fig. 4. Photomicrograph of sample PMOG-441, a very low-grade quartz-rich metasandstone from the Punta Mogotes Formation. Foliation S1 is defined by the preferred orientation of white mica $(\mathrm{WM}=$ Illite, ) and the long axis of quartz grains.

of the Balcarce Formation indicates a completely different source area for the younger siliciclastic platform of the Tandilia belt - one that supplied detrital zircons as young as c. $475 \mathrm{Ma}$ as well as conspicuous populations of "Brasiliano" (570-675 Ma, Rapela et al., 2007; Van Staden et al., 2010), Mesoproterozoic (1170 Ma) and Late Palaeoproterozoic (1680-1890 Ma) ages.

Exposures of the Palaeoproterozoic basement disappear below the Balcarce Formation some $50 \mathrm{~km}$ west of the coast (Fig. 3b). NNEtrending magnetic and gravimetric anomalies occur about $20 \mathrm{~km}$ east of Mar del Plata, suggesting an important change in the subsurface basement (Kostadinoff, 1995). The only direct evidence for the rocks beneath the quartz-arenites of the Balcarce Formation at the Atlantic tip of the Tandilia belt comes from the $504 \mathrm{~m}$ deep Punta Mogotes borehole $\left(38^{\circ} 05^{\prime} 30^{\prime \prime} \mathrm{S} ; 57^{\circ} 32^{\prime} 42^{\prime \prime} \mathrm{W}\right.$; Figs. 2, 3b). Petrographic and mineralogical descriptions of the core were made by Marchese and Di Paola (1975, see also earlier references in this paper). From the surface to a depth of $406 \mathrm{~m}$ the lithology is typical of the Balcarce Formation, dominated by quartz-rich flat-lying sandstones, which vary from fine to coarse, with subordinate conglomerates. An unconformity separates these from the Punta Mogotes Formation, a low-grade metamorphic sequence dominated by meta-siltstones and metapelites, and subordinate meta-sandstones. The total thickness but $90 \mathrm{~m}$ has been proven. The meta-sandstones show a foliated fabric defined by illite and poorly-oriented quartz grains (Fig. 4). The detrital components are $\mathrm{Pl}-\mathrm{Kfs}-\mathrm{Ms}-\mathrm{Chl}-\mathrm{Tu}-\mathrm{Zr}-\mathrm{Op}$ and lithic fragments of chert (mineral abbreviations, as elsewhere, after Kretz, 1983). Quartz veins are widespread.

The illite crystallinity index indicates metamorphic conditions between anchizone and epizone, while four $\mathrm{K}-\mathrm{Ar}$ ages between $576 \pm$ $13 \mathrm{Ma}$ and $615 \pm 14 \mathrm{Ma}$ obtained on concentrates of clay minerals have been interpreted as dating the last thermo-tectonic episode that affected these rocks (Cingolani and Bonhomme, 1982).

\section{Geochronological and isotopic results}

U-Th-Pbanalyse of zircon were made using SHRIMPs RG and I at the Research School of Earth Sciences, The Aus ralian National University, Canberra, Australia, following the methods of Williams (1998, and references therein) as in our previous work (e.g., Rapela et al., 2007). Data were reduced using the SQUID Excel macro of Ludwig (2001). Probability density plots with stacked histograms, Tera-Wasserburg and Wetherill Concordia plots were carried out using ISOPLOT/Ex (Ludwig, 2003). Prior to ploting, analyses that were $<90 \%$ concordant and with $>2.5 \%{ }^{206} \mathrm{~Pb}$ of common origin were removed. For grains with ages above $1.0 \mathrm{Ga}$ the ${ }^{207} \mathrm{~Pb} /{ }^{206} \mathrm{~Pb}$ age was plotted, whereas for grains less than $1.0 \mathrm{Ga}$ the ${ }^{206} \mathrm{~Pb} /{ }^{238} \mathrm{~Pb}$ was chosen.
Lu-Hf and oxygen isotopic analyses were also performed at the Research School of Earth Sciences, Australian National University. After selecting zircon populations of known age, and re-polishing the epoxy mounts, oxygen analyses were carried out using SHRIMP II, while Lu-Hf analyses were performed on a Neptune MC-ICPMS coupled with a HelEx $193 \mu \mathrm{m}$ ArF Excimer laser ablation system, following procedures described in Munizaga et al. (2008). Full analytical results are presented as a Supplementary Appendix to this paper.

Five samples from the borehole core were analyzed. Two samples from below $410 \mathrm{~m}$ belong to the Punta Mogotes Formation, while the remaining samples from depths of $406 \mathrm{~m}, 339 \mathrm{~m}$ and $233 \mathrm{~m}$ belong to the Balcarce Formation. U-Pb data are shown in Figs. 5 and 6. Lu-Hf and oxygen data were also obtained for three of these samples (Fig. 8).

\subsection{Punta Mogotes Formation}

Both samples of the Punta Mogotes Formation are green to pale brown low-grade meta-siltstones and fine grained meta-sandstones, with a weak S1 foliation formed by oriented clay minerals and quartz (Fig. 4) Sample PMOG-441 was recovered from a depth of $441 \mathrm{~m}$ in the borehole, while PMOG is a composite sample formed of metasiltstone chips from 415,427 and $451 \mathrm{~m}$.

The detrital age patterns of the two samples are complex but remarkably similar (Fig. 6), suggesting a similar source for at least the upper section of the Punta Mogotes Formation. The most significant characteristic is a conspicuous younger peak at about $770 \mathrm{Ma}$, defined by concordant igneous grains in the range of $740-840 \mathrm{Ma}(17-22 \%$ of the total analyses). The majority of the older detrital ages are concentrated in two intervals: a Mesoproterozoic group at 940$1330 \mathrm{Ma}(20-27 \%$, with peaks at 1250 and $1270 \mathrm{Ma})$ and a Late Palaeoproterozoic group at $1710-2030 \mathrm{Ma}$ (25\%, with peaks at 1735 and $1835 \mathrm{Ma}$ ). The remaining detrital ages can be subdivided in three distinct sub-populations, which are also important for identification of the probable sources: (i) 1420-1560 Ma Mesoproterozoic zircons (7-15\%), (ii) Early Palaeoproterozoic and Archaean zircons (3-7\%) at 2420-2480, 2660-2670 and 2850-2870 Ma, and (iii) a small (5-6\%) subpopulation in the range 2069-2202 Ma.

$\varepsilon^{18} \mathrm{O}$ and $\varepsilon \mathrm{Hf}_{\mathrm{t}}$ values for the detrital zircons (the latter calculated to the time of zircon crystallization) show an enormous range of values of $+3.7 \%$ to $+11.8 \%$ and -25 to +20 respectively, indicating polygenetic protoliths. The $740-840 \mathrm{Ma}$ group of detrital grains has predominantly negative $\varepsilon \mathrm{Hf}_{\mathrm{t}}$ (down to -25 ) and, with the exception of two grains, $\delta^{18} \mathrm{O}>6.5 \%$; the data depart considerably from depleted mantle values in terms both parameters (Fig. 8). Comparison with analyses of 770 and $840 \mathrm{Ma}$ A-type granites from the Western Sierras Pampeanas, for which U-Pb ages were published by Baldo et al. (2006) and Colombo et al. (2009), shows a clear difference in both parameters (Fig. 9), ruling out the possibility of derivation of the detrital grains from this igneous province.

\subsection{Balcarce Formation}

A well-constrained detrital age pattern for the lower and middle sectors of the overlying Balcarce Formation is demonstrated in Fig. 7c-e. Analyses of two surface samples, at the type section in Balcarce (sample FBA-264, Rapela et al., 2007) and at the Sierra del Volcán (diamictite, Van Staden et al., 2010), are shown for comparison in Fig. 7a, b. Samples PMOG-406 and PMOG-233 are quartz arenites with a marked uniform texture, composed of monocrystalline and equidimensional quartz grains cemented by syntaxial quartz and less commonly by kaolinite. Most quartz grains show trains of fluid inclusions, and rapid to wavy extinction. Polycrystalline quartz grains are less frequent, and they are formed of inequigranular crystals with sutural contacts. Among the heavy mineral population, greenish-brownish tourmaline and zircon grains prevail. Sample PMOG-339 is similar to previously described 


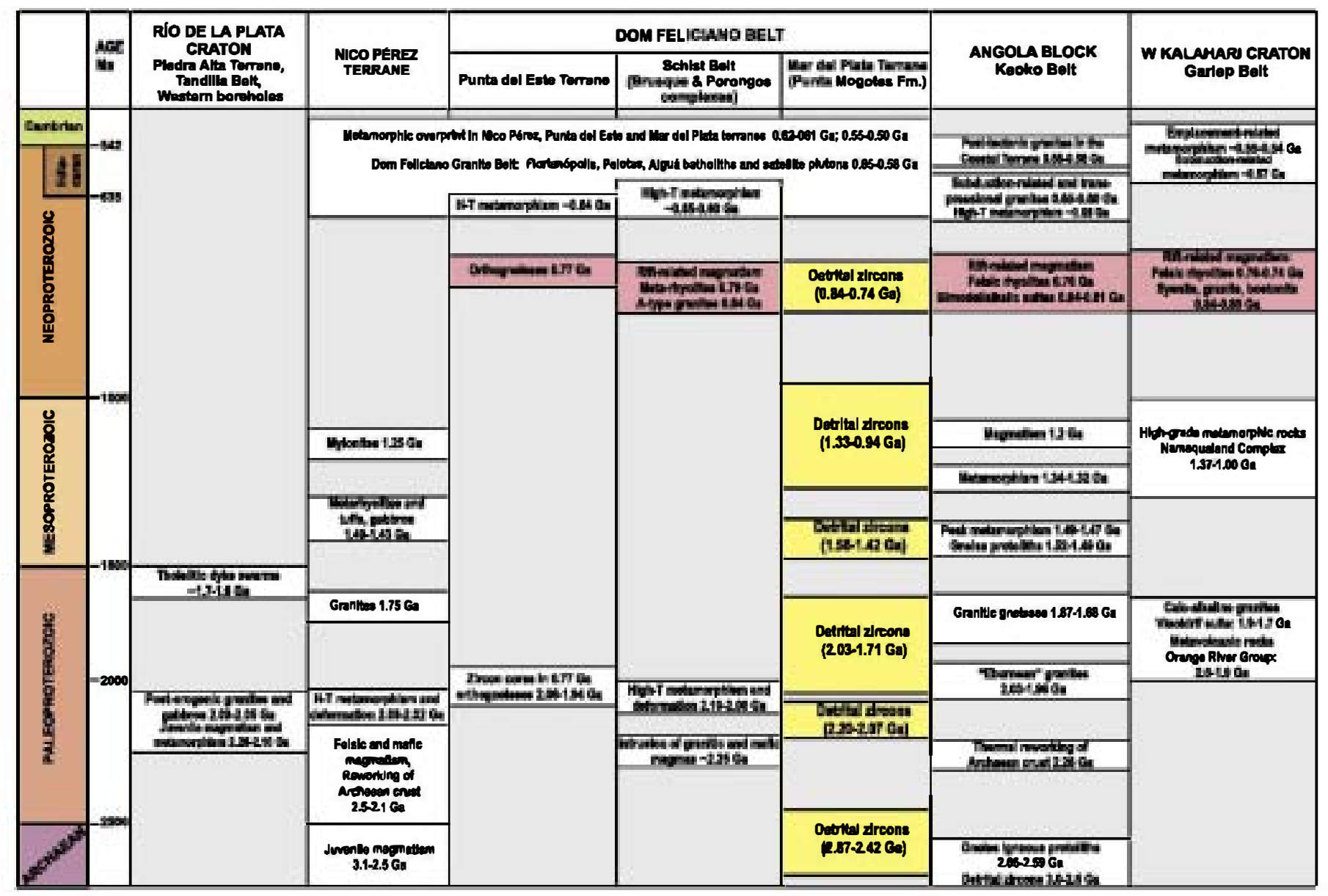

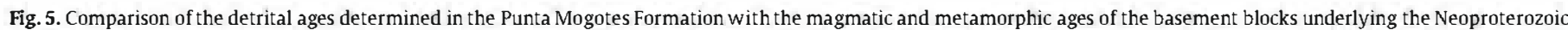

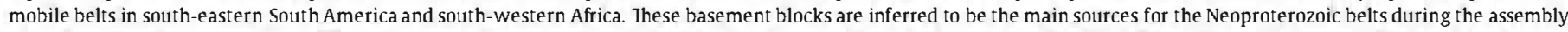

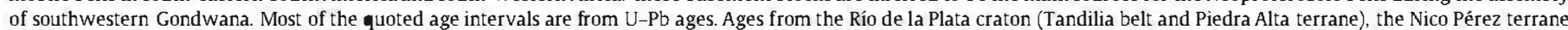

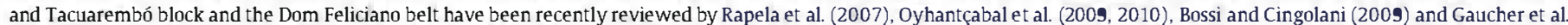

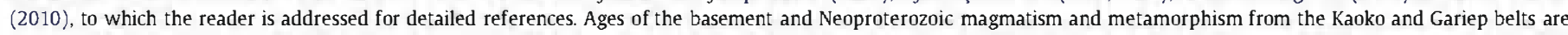

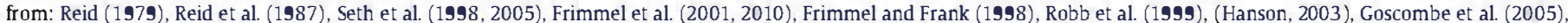
Gray et al. (2006, 2008), Goscombe and Gray (2007), Becker et al. (2005, 2006),; Kröner et al. (2004), Eglington (2006) and Konopásek et al. (2008).

samples, though its matrix proportion is higher (c. 10\%). The distribution of the fine-grained material is not uniform, since it appears as patches of diagenetically-deformed and crushed aggregates of sericite-kaolinite, strongly suggesting that the fine-grained components are muddy in traclasts (pseudomatrix).

All samples of the Balcarce Formation show peaks at 505-560 Ma and $635-670 \mathrm{Ma}$, whereas the conspicuous c. $770 \mathrm{Ma}$ peak of the Punta Mogotes Formation is absent or poorly defined. In the sample for which $\mathrm{O}$ and $\mathrm{Hf}$ data were obtained (PMOG-233), both $8^{18} \mathrm{O}$ and $\varepsilon \mathrm{Hf}_{\mathrm{t}}$ values are highly variable, ranging from $+3.8 \%$ o to $+10.6 \%$ and -14 to +11 , respectively. Within this range, the $635-670$ Ma detrital grains also show a wide range of isotopic compositions, with $\delta^{18} \mathrm{O}$ of both c. $+4.5 \%$ and $6.8-8.2 \%$ and $\varepsilon \mathrm{Hf}_{\mathrm{t}}$ of +5 to -15 , suggesting provenance from a mixture of mantle and crust-derived rocks (Fig. 8). The youngest detrital zircons in the sample located in the uppermost part of the sequence indicate that the Balcarce Formation cannot be older than Early Ordovician (475 Ma, sample FBA-264, Fig. 7a). The youngest detrital peaks in the Punta Mogotes borehole samples and the Sierra del Volcán diamictite vary in age from 505 to $540 \mathrm{Ma}$ (Fig. 7b-e), indicating that the lower part of the Balcarce sequence cannot be older than Middle to Early Cambrian. These youngest grains in PMOG-233 have $\varepsilon \mathrm{Hf}_{\mathrm{t}}$ of 0 to -9 and ${ }^{18} \mathrm{O}>7.7 \%$, suggesting a crustdominated source.
There are conspicuous Palaeoproterozoic peaks at $2155 \mathrm{Ma}$ and 2160 Ma in samples PMOG-406 and PMOG-233 (20-32\%), not seen in PMOG-339 and FBA-264. Discordia lines calculated for the Palaeoproterozoic grains in PMOG-406 and PMOG-233 define upper intercepts at $2149 \mathrm{Ma}$ and $2168 \mathrm{Ma}$ (Fig. 7c,e), indicating a Pb-loss episode affecting the source area of the Palaeoproterozoic zircon grains. Late Palaeoproterozoic (1730-2000 Ma, 7-12\%) and Mesoproterozoic (c. $1040 \mathrm{Ma}, 7-9 \%$ ) peaks are observed in all samples. All the analyzed Mesoproterozoic grains and most of the Palaeoproterozoic ones show positive $\mathrm{\varepsilon Hf}_{\mathrm{t}}$, suggesting provenance from predominantly juvenile sequences (Fig. 8).

\section{Discussion}

\subsection{The Mar del Plata Terrane}

Oyhantçabal et al. (2010a) have recently proposed re-definition of the Río de la Plata craton as a Palaeoproterozoic continental block that did not undergo rejuvenation during the Brasiliano/Pan-African orogeny. These authors identify the eastern limit of the craton in Uruguay as the SYSZ (Fig. 3a), based on the contrasting geological history between the Punta Alta and Nico Pérez terranes. The same authors extrapolated the SYSZ southwards as far as the off-shore limit 


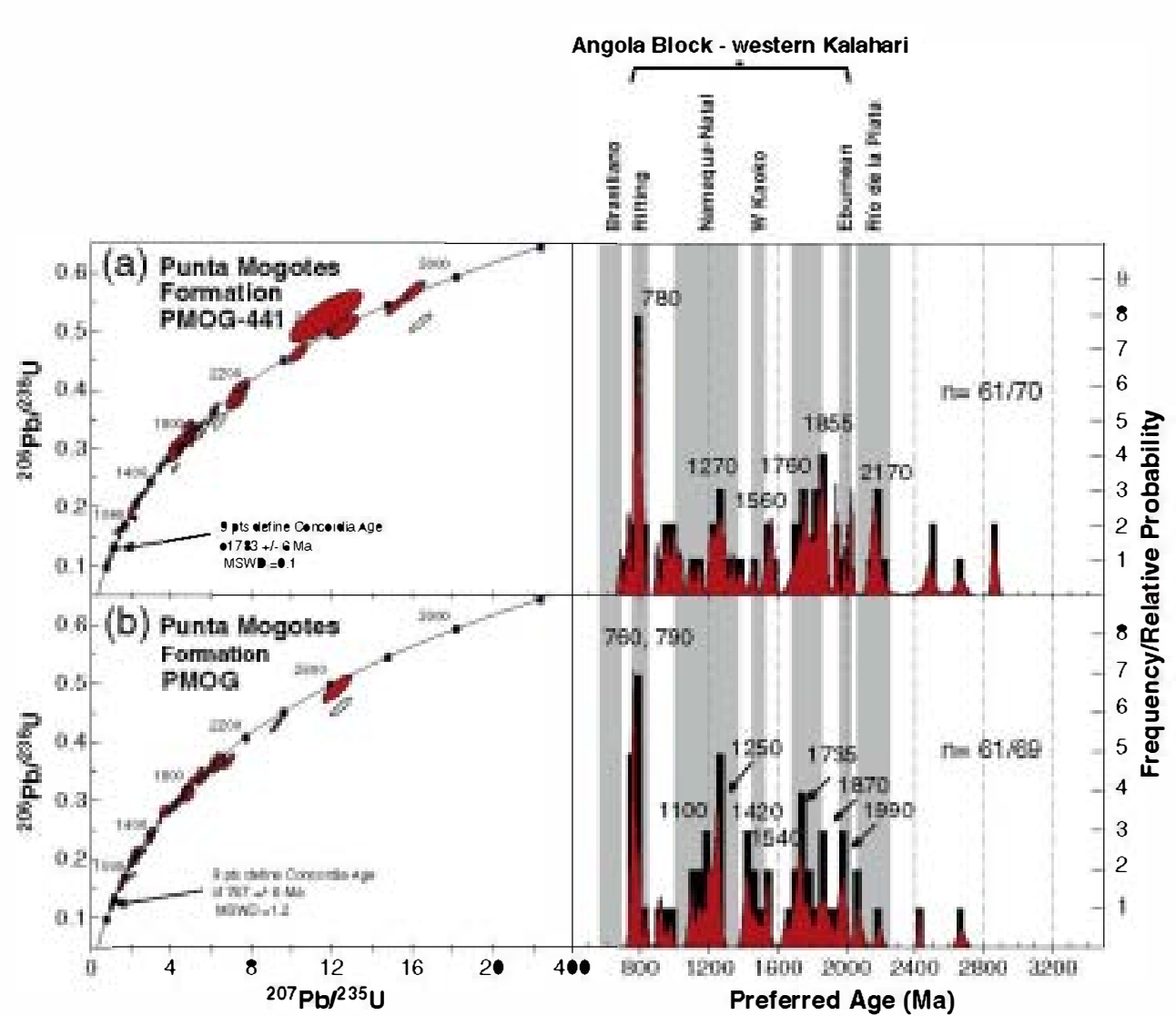

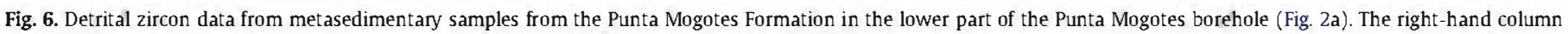

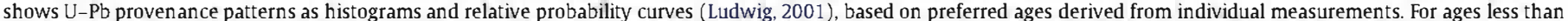

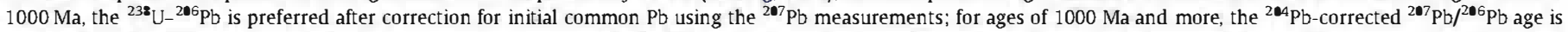

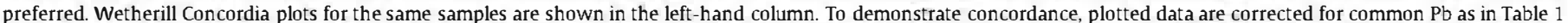

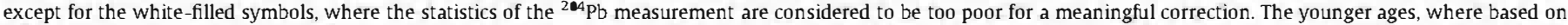

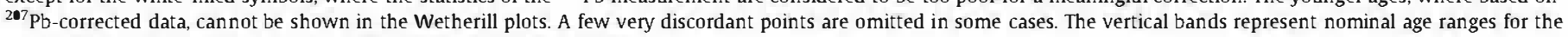
potential provenance areas based on published data summarized in Fig. 4 .

of the continental platform (Fig. 2). The new results on the Punta Mogotes borehole indicate, however, that the eastem limit of the Rio de la Plata craton is located inland, c. $20 \mathrm{~km}$ west of the city of Mar del Plata. The supracrustal rocks of the Punta Mogotes Formation and its inferred underlying basement must be part of a different continental block, here named the Mar del Plata terrane (Fig. 3b). Evidence supporting the existence of the Mar del Plata terrane is summarized below:

a) NNE-trending magnetic and gravimetric anomalies show contrasting behavior of the rocks beneath the modern cover compared to the typical Palaeoproterozoic rocks of the Tandilia belt (Kostadinoff, 1995).

b) The c. $600 \mathrm{Ma} \mathrm{K}-\mathrm{Ar}$ ages for low-grade meta-siltstones of the Punta Mogotes Formation (Cingolani and Bonhomme, 1982), have no equivalents in the Tandilia Belt, nor is there evidence of Neoproterozoic metamorphic overprinting of the Palaeoproterozoic basement and its sedimentary cover.

c) The detrital zircons of the Punta Mogotes Formation are dominantly derived from lithologies not observed in the Río de la Plata craton (Figs. 4, 5). Palaeoproterozoic detrital zircons that might be considered within the range of the craton constitute only $5-6 \%$ of the population (Fig. 6).

d) The average thickness of the Early Palaeozoic Balcarce Formation covering the Tandilia belt is c. $150 \mathrm{~m}$ (Zimmermann and Spalletti, 2009), but this increases to c. $400 \mathrm{~m}$ in the Punta Mogotes borehole at the Atlantic coast (Fig. 3b), suggesting an abrupt, fault-controlled, change in palaeotopography at the eastern limit of the Tandilia belt.
These contrasts in characteristics between the Mar del Plata terrane and the adjacent Tandilia belt are very similar to those observed across the SYSZ in Uruguay between the Piedra Alta terrane and the Nico Pérez terrane/Dom Feliciano belt (Fig. 2). The SYSZ is here tentatively extrapolated to the west of Mar del Plata and the left-lateral displacement of the Rio de la Plata craton along this shear zone is considered to have occurred at $584 \pm 13 \mathrm{Ma}$, based on a $\mathrm{Pb}-\mathrm{Pb}$ isochron for synlinematic granites emplaced in the fault (Oyhantaçabal et al., 2007,2009 ). This movement was probably coeval with the last, sinistral, displacement on the Sierra Ballena Shear Zone (SBSZ, Fig. 3a), which occurred at 586 to $576 \mathrm{Ma}$ (Oyhantçabal et al., 2010c). Therefore the eastern limit of the Río de la Plata craton may well be a fault where the SYSZ and the SBSZ merge. This would explain why the Nico Pérez terrane disappears to the south.

In summary, the Río de la Plata craton is bounded by late Neoproterozoic to early Palaeozoic megashears that are responsible for its translation from a missing root in the west (present coordinates) and for the final involvement of the craton in the closure of southern Adamastor Ocean. The effects of these shear zones and faults (Fig. 1) were the following: a) in the north and northeast the late Neoproterozoic SYSZ displaced the craton clockwise for a probable length of several hundred kilometers, b) in the west the Córdoba fault juxtaposed the craton and the Pampean orogenic belt in the middle to late Cambrian (Rapela et al., 2007; Iannizzotto, 2010; Verdecchia et al., 2011,), and c) in the south the Sierra de la Ventana fault juxtaposed the craton and the Brasiliano/Pan-African basement, implying a large right-lateral displacement. Iater on, this fault controlled a late 
Angola Block - western Kalahari

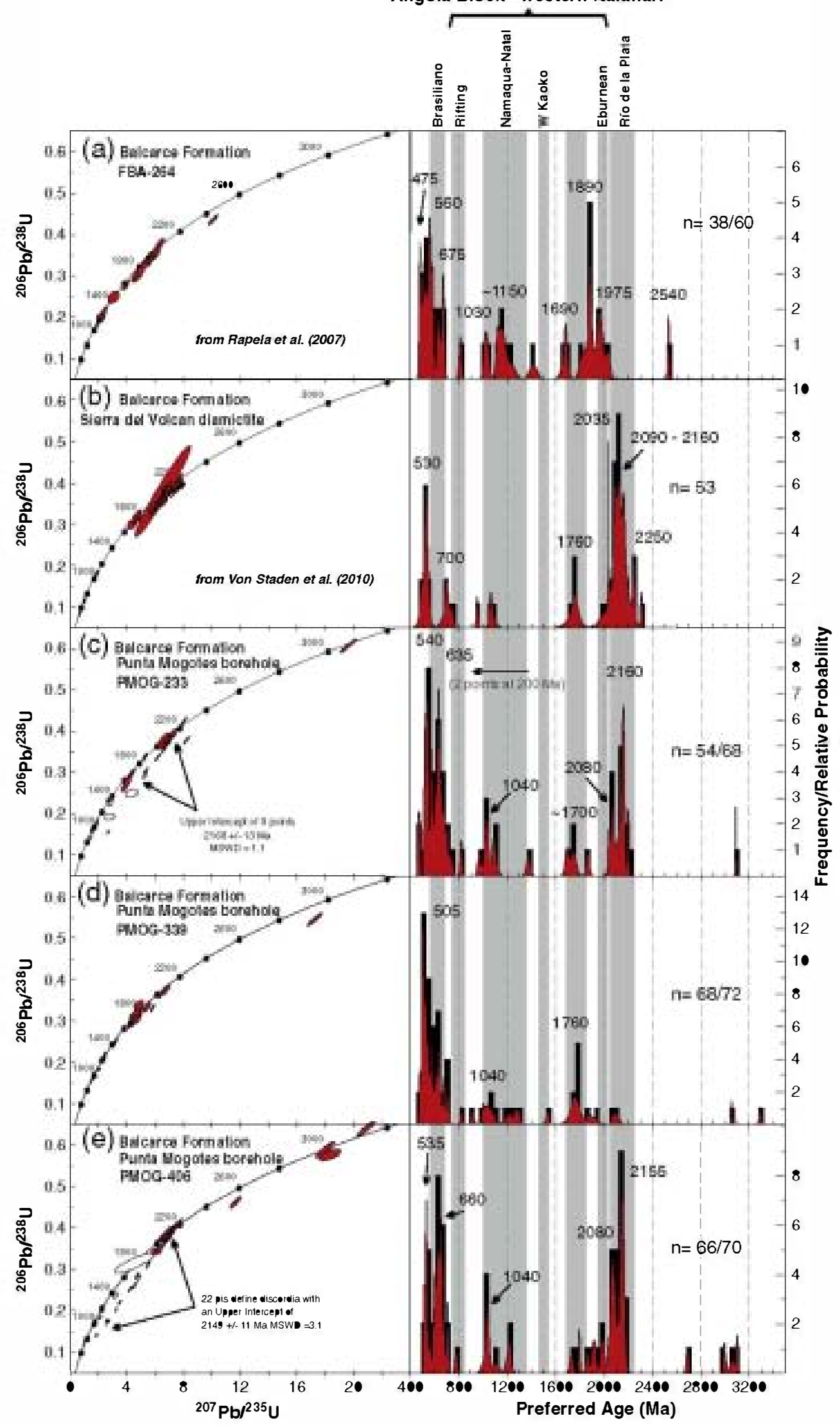

Fig. 7. U-Pb provenance patterns and Concordia plots for sedimentary rocks of the Ordovician Balcarce Formation (Fig. 2a). (a) and (b) show data from surface samples from the literature while (c), (d) and (e) are new SHRIMP data from different levels of the Punta Mogotes borehole (where the numbers after the PMOG acronym indicate depth in meters). See caption of Fig. 5 for details of age calculation and graphical presentation. 

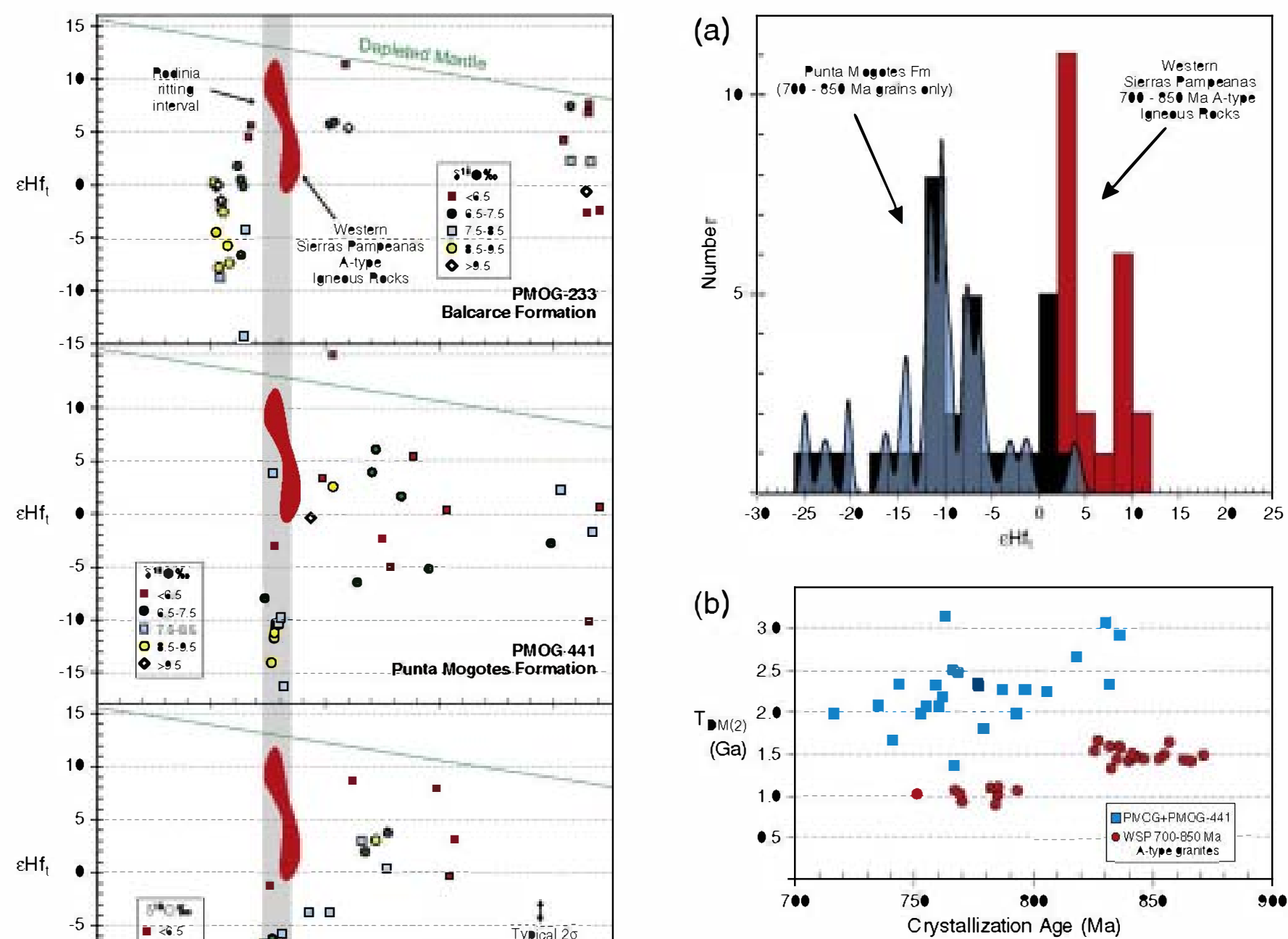

Fig. 9. a) Histogram of the $\varepsilon \mathrm{Hf}_{\mathrm{t}}$ contrasting the isotopic signature of the $740-840 \mathrm{Ma}$ detrital zircons of the Punta Mogotes, with that of the 770 and $840 \mathrm{Ma}$ A-type granites of the Western Sierras Pampeanas (Baldo et al., 2006; Colombo et al., 2009), which are dominated by juvenile mantle components (Rapela and Pankhurst, unpublished data). b) Model $T_{0 M}$ ages of the Punta Mogotes detrital zircons are Palaeoproterozoic, suggesting derivation from old crustal rocks. In contrast the mantle derived A-type granites of the Western Sierras Pampeanas have Mesoproterozoic model ages.

Fig. 8. $\varepsilon \mathrm{Hf}_{\mathrm{t}}$ vs U-Pb SHRIMP crystallization age for detrital grains from the Punta Mogotes and Balcarce formations. Oxygen isotope composition is shown as intervals of ${ }^{18} \mathrm{O}$ in each sample. The depleted mantle curve is derived from chondritic values (Bouvier et al., 2008) and the present-day depleted mantle value (Vervoort and Blichert-Toft, 1999). Note that most of the $740-840$ Ma grains from the Punta Mogotes Formation show negative $\varepsilon \mathrm{Hf}_{\mathrm{t}}$ and high $\mathbf{~}^{12} \mathrm{O}$ indicating derivation from a crustal source.

Cambrian rift, which evolved into a sedimentary basin active throughout the Palaeozoic until its inversion in the Permian during the Gondwanan orogeny (Rapela et al., 2003).

\subsection{Inferred source for the Punta Mogotes Formation}

In Fig. 9, the combined detrital pattern of the Punta Mogotes Formation is compared with patterns reported from Neoproterozoic and Early Palaeozoic sedimentary sequences of southeastern South America (Tandilia belt, Piedra Alta terrane and Dom Feliciano belt, Fig. 2), and the Kaoko and Gariep belts of southwestern Africa (Figs. 1, 10 ). The concordant detrital grains in the range $740-840$ Ma that are the main feature of the Punta Mogotes Formation (Fig. 10a) but which are absent from the Neoproterozoic successions of the Río de la Plata craton (Fig. 10f, g, h), define a maximum age for the siliciclastic succession. Further constraints on the age of the Punta Mogotes Formation are the c. $600 \mathrm{Ma} \mathrm{K}-\mathrm{Ar}$ metamorphism that limits the

minimum age, and the absence of Brasiliano/Pan-African detrital zircon ages (560-690 Ma), despite the fact that they represent a widespread event in southwestern South America and are observed in all samples of the overlying early Palaeozoic Balcarce Formation (Fig. 7). This suggests that the sequence is older than about $680 \mathrm{Ma}$ and younger than about $720 \mathrm{Ma}$ (the youngest individual concordant detrital zircon).

In the Gariep, Damara and Kaoko belts of southwestern Africa, the entire time span from c. 728 to c. $840 \mathrm{Ma}$ is characterized by widespread extension and rifting (Fig. 11, Jacobs et al., 2008), associated with alkaline igneous plutons, carbonatites and felsic magmatism (Miller, 1983; Hoffman et al., 1996; Frimmel et al., 2001; Jacobs et al., 2008; Konopásek et al., 2008; Master, 2009 and references therein). In the Gariep belt, the record of alkaline events started with granitic-to-syenitic belts at $833 \pm 3$ Ma and was followed by intrusion of bostonitic dykes and related volcanic rocks at $801 \pm$ $8 \mathrm{Ma}$. Rifting continued at $771 \pm 6 \mathrm{Ma}$ along a southwest-northeast linear trend, and ended with rift sediment deposition and felsic volcanism at $741 \pm 6 \mathrm{Ma}$ (Frimmel et al., 2001). Both juvenile and crust-derived melts resulting from continental stretching and mantle upwelling are often observed in Neoproterozoic rift systems of the Congo and Kalahari cratons. The palaeogeographic arrangement 
Angola Block - western Kalahari

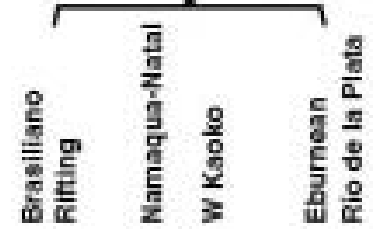
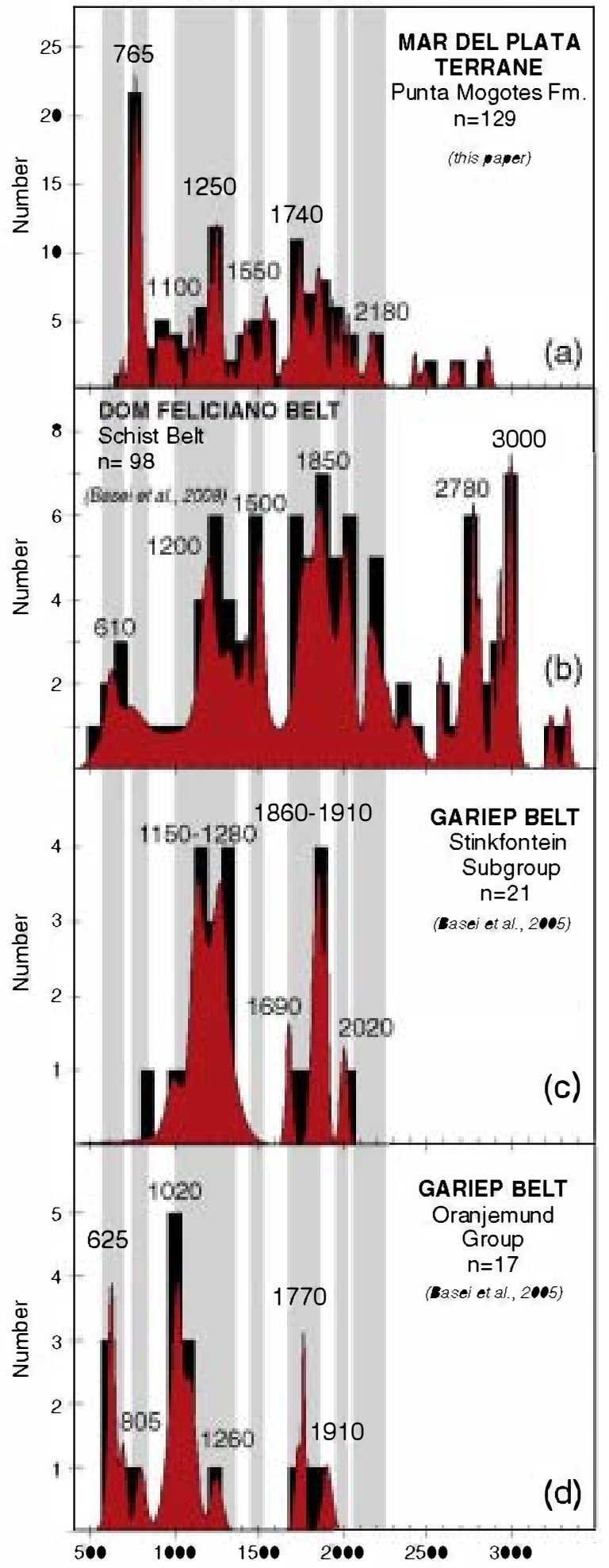

Angola Block - western Kalahari

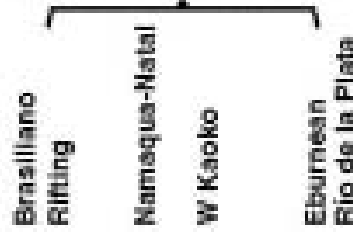

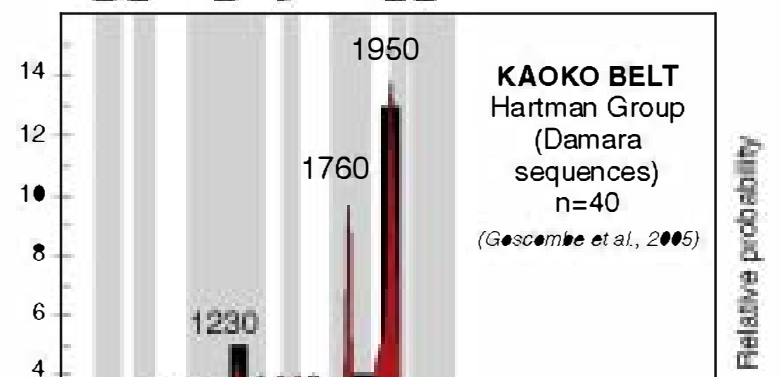

(e)

TANDILIA BELT

Sierras Bayas

Group

Villa Mónica Fm.

FSB 260; $n=54$

(Rapela et al, 2007)

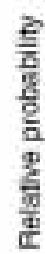

(f)

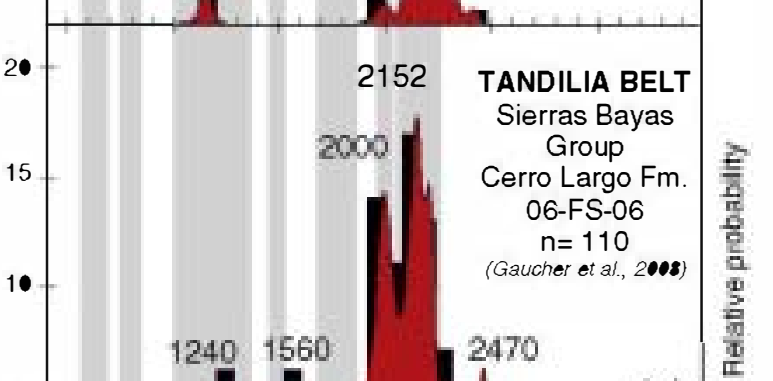

(g)
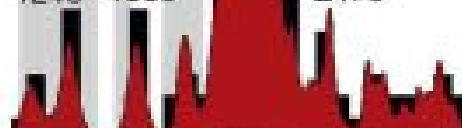

(g)

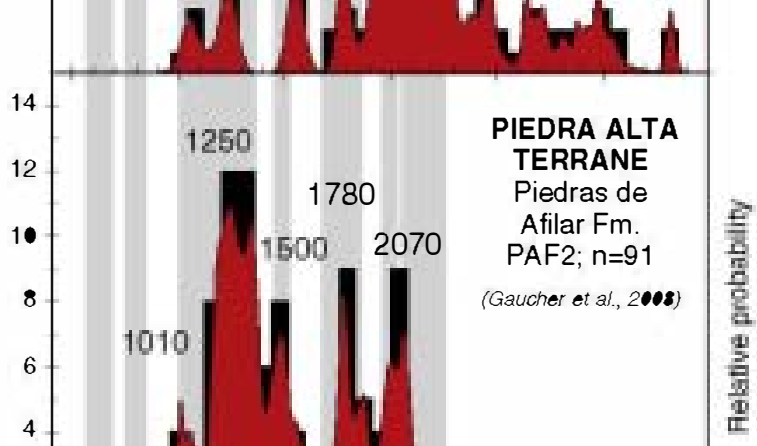

Preferred Age Ma (<10\% discordant) 


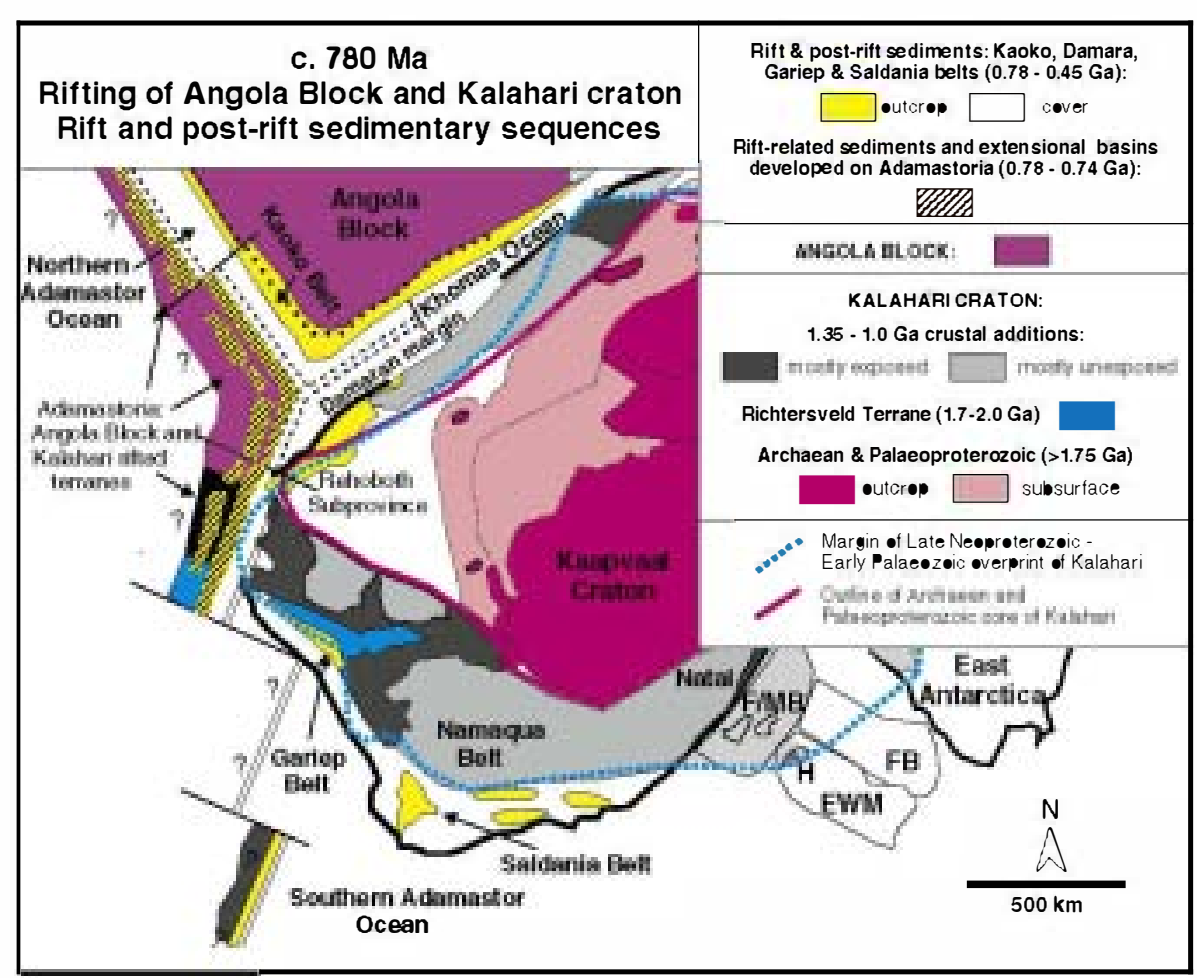

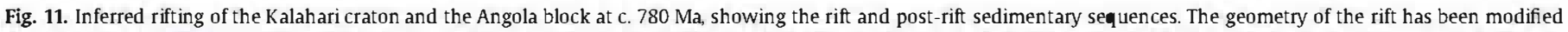

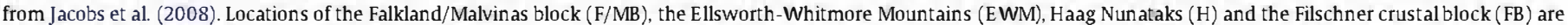

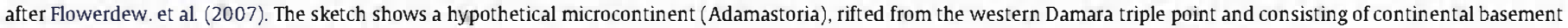
rocks from western Angola and northwest Kalahari.

between the two cratons during the Neoproterozoic-Early Palaeozoic interval has been a long debated topic (see Johnson et al., 2005; Gray et al., 2008; Frimmel et al., 2010 as examples of different approaches). However, recent results show that while the timing of rift magmatism was roughly coeval in the Gariep, Damara and Kaoko belts, in the Congo craton this occurred as early as 880-920 Ma, as recorded in the Lufilian, West Congo and Araçuaí belts (Frimmel et al., 2010). There is an increasing amount of evidence indicating that the Angola block, located to the north of the Damara belt, was a separate plate that was not part of the Congo craton (Porada and Berhorst, 2000); Heilbron et al. (2008 and references therein). Furthermore, the coeval Neoproterozoic rifting of the Damara, Kaoko and Gariep belts and their parallel tectonic evolution suggest that at that time the Angola block \& was attached to the Kalahari rather than the Congo craton (Gaucher et al., 2008; Frimmel et al., 2010). This hypothesis is adopted here and shown in Fig. 11, where there is a single connected rift affecting the Kalahari craton and the Angola block.

Rift-related alkaline magmatism often shows mantle-dominated signatures. For example the syn-rift 700-800 Ma detrital zircons in the internal part of the Damara orogen show positive $\varepsilon \mathrm{Hf}_{\mathrm{t}}$ values (Newstead et al., 2009). On the other hand, addition of mantle-derived melts to the crust should lead to an elevated crustal geotherm, and high-T, low-P metamorphism should be expected in the lower crust at such time (Warren and Ellis, 1996). Evidence for such metamorphism in an extensional regime related to the Neoproterozoic continental breakup is found in the Zambezi belt and the western sector of the Namaqua metamorphic belt (Robb et al., 1999 and Vinyu et al., 1999). The timing of these events in the Angola block and Kalahari craton is essentially the same as the $740-840 \mathrm{Ma}$ detrital zircon age range observed in the Punta Mogotes Formation (Figs. 4, 5, 9a) and is a strong argument for connecting these sediments with the Neoproterozoic rifting in the Kalahari craton and the Angola block.

Neoproterozoic pre-rift,syn-rift and post-rift sedimentary sequences were deposited on the Angola block and westem Kalahari passive margins, in the Kaoko, Damara and Gariep belts (Fig. 11). Protracted late Neoproterozoic to Cambrian deformational, metamorphic and magmatic events reworked these sequences (Goscombe et al., 2005 and references therein). When comparing the detrital pattems of Neoproterozoic sequences from these belts, they show some similarities reflecting the influence of widespread igneous-metamorphic events and large provinces characteristic of the African cratons (e.g., the 1700-2000 Eburnean event and the 1000-1370 Natal-Namaqua province).

However, there are significant differences in basement composition and age between the Kaoko and the Gariep belts (Fig. 5). The Kaoko belt is dominated by major strike-slip shear zones within highgrade amphibolite facies turbidites of the Damara Supergroup, incorporating basement slivers and sheared Pan-African granitoids (Dürr and Dingeldey, 1996; Konopásek et al., 2005; Gray et al., 2006; Goscombe and Gray, 2008 and references therein). The basement slivers include sectors with granitoid gneisses of c. 2.59-2.65 Ga, c. 1.96-2.03 Ga, c. $1.68-1.78 \mathrm{Ga}$, c. $1.45-1.52 \mathrm{Ga}$ (Seth et al., 1998; Kröner et al., 2004) and c. $1.2 \mathrm{Ga}$ (Frimmel et al., 2010). Arc-related granites and migmatitic gneisses of 1.73-1.87 Ga have been reported in the pre-Damaran basement of northern Namibia while to the north of the Kaoko belt, there is robust geochronological evidence indicating that Eburnean igneous and metamorphic rocks were affected by a 1320-1340 Ma upper amphibolite facies metamorphism (Seth et al., 2005; Frimmel et al., 2010 and references therein). The detrital zircon age pattern of Neoproterozoic metasedimentary rocks from the

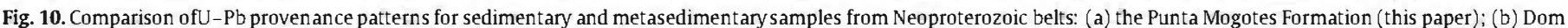

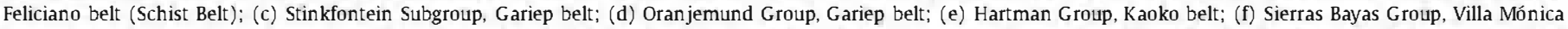

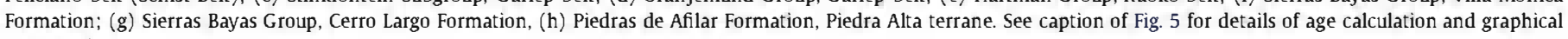
presentation. 
Orogen Core of the Kaoko belt exhibits variable proportions of all these components, grouping at 1950, 1230, 1760, 1440, 1005 and $2510 \mathrm{Ma}$, given in decreasing relative abundance (Goscombe et al., 2005) (Fig. 10e). It must also be observed here that the ages of several lithological units observed in the basement of the Kaoko Belt, have also been recognized in the Nico Pérez terrane (Fig. 3a), including the Neoarchaean thermal reworking and the rather uncommon 1.41.5 Ga magmatic episode (Fig. 5). In contrast, the Gariep belt (Fig. 11) is mostly of low metamorphic grade, consisting of stacked oceanic thrust-sheets, including mélange, metagreywacke turbidites and metabasalts, thrust over the passive continental margin of the Kalahari craton (Frimmel, 1995, 2000; Hälbich and Alchin, 1995; Gray et al., 2006 and references therein). The basement on which the Gariep belt was developed is relatively simple compared with that of the Kaoko (see summary in Fig. 5). Archaean rocks are not exposed, only occurring far to the east in the Kaapvaal craton (Fig. 11). The basement geology is dominated by the c. 1.0-1.25 Ga high-grade metamorphic rocks of the Namaqualand metamorphic complex (Bushmanaland Subprovince, Robb et al., 1999; Eglington, 2006), which occurs within the Richtersveld terrane, consisting in turn of juvenile 1.7-1.9 Ga granites of the Vioolsdrift suite (Reid, 1979) and 1.9-2.0 Ga metavolcanic rocks of the Orange River Group (Reid et al., 1987). The influence of this basement is observed in the fluvio-deltaic sediments of the Stinkfontein Subgroup, which accumulated in the 740-770 Ma continental rift on the western margin of the Kalahari craton (Frimmel and Frank, 1998). These sediments show a bi-modal detrital pattern defined by concordant grains at c. 1000-1300 (Namaqua component) and c. 1700-2000 Ma (Richtersveld component), with a minor peak at $820 \mathrm{Ma}$ (Basei et al., 2005) (Fig. 10c). The same dominant peaks are observed in siliciclastic sediments of the Oranjemund Group of the Gariep belt (Fig. 10d) and the Rocha basin in Uruguay (Fig. 3a), which are interpreted as having been deposited in the same back-arc basin (Basei et al., 2005). In the latter cases the Richtersveld and Namaqua components are accompanied by a conspicuous c. $620 \mathrm{Ma}$ Brasiliano/Pan-African peak (Fig. 10d). The absence of Archaean and 1420-1560 Ma Mesoproterozoic ages in the Gariep belt, both in the basement (Fig. 5) and as a detrital zircon component in Neoproterozoic sequences (Fig. 10c, d), is the most important difference with the Kaoko belt. This notable lack of Mesoproterozoic igneous rocks older than $1.4 \mathrm{Ga}$ in the northwestern sector of the Kalahari craton has been ascribed to post-1.49 Ga convergence with the Angola block (Becker et al., 2006).

On the other hand, the basement of the Río de la Plata craton only consists of 2.05-2.26 Ga Palaeoproterozoic igneous-metamorphic complexes, intruded by 1.6-1.7 Ga tholeiitic dyke swarms (Fig. 5). Flat-lying sedimentary sequences covering the craton show either dominant or significant detrital peaks within these ranges, but in some cases also important late Mesoproterozoic and Archaean peaks, suggesting provenance from outside the craton (Rapela et al., 2007; Gaucher et al., 2008) (Fig. 10f, g, h). Neoproterozoic detrital zircons are absent from all these sequences cropping out near the eastem side of the craton and they lack evidence of any Neoproterozoic metamorphic overprint. This seems best explained if the whole region of the Rio de la Plata craton was located far away from the influence of the Brasiliano/ Pan-African event i.e., as it would have been prior to the left-lateral displacement along the SYSZ at c. $580 \mathrm{Ma}$. The only alternative explanation is that the Sierras Bayas Group and the Cerro Negro Formation are older than Neoproterozoic, which is not consistent with the combined evidence inferred from race fossils, $\mathrm{C}-\mathrm{O}$ chemostratigraphy and $\mathrm{Sr}$ isotopes for at least the upper part of these two sequences (Gómez Peral et al., 2007; Gaucher et al., 2009; Poiré and Gaucher, 2009).

In either case, the sedimentary rocks overlying the craton must have been deposited before the displacement of the craton along the SYSZ, i.e., they must be older than c. 580 Ma. Moreover, the transport direction of these clastic sedimentary rocks was from the northwest
(Dalla Salda and Iñiguez, 1979; Gaucher et al., 2008), which strengthens the idea that source areas were different from those of sedimentary rocks involved in the Dom Feliciano orogeny.

An important conclusion from the above discussion is that detrital age groups observed in the Punta Mogotes Formation (Fig. 10a) closely match the main events in the basement of the Kaoko belt (Angola block) and in the Nico Pérez terrane (Fig. 5). Most of these peaks are also observed in detrital zircon patterns for the Neoproterozoic Damara sequence in the Kaoko belt (Fig. 10e) and in the Damara orogen, where the 700-800 Ma peak is well developed (Newstead et al., 2009). Not only are the typical Ebumean and Namaqua components present in the Punta Mogotes pattern, but also the $1420-1560 \mathrm{Ma}$ interval, which is not common in Africa, with a possible igneous protolith of this age only known in the basement of the western and central Kaoko belt (Kröner et al., 2004) (Fig. 10a). Metavolcanic rocks at $1429 \pm 21$ Ma and metagabbros at $1492 \pm$ Ma have been also identified in the Nico Pérez terrane (Oyhantaçabal et al., 2005; Gaucher et al., 2010) and in the Betara region of southwestern Brazil (1.50-1.45 Ga, Siga et al., 2011), strengthening the proposed correlation.

The similarities described here are considered important evidence for the Angola block being the area source for the Punta Mogotes metasedimentary rocks, while the conspicuous $840-740$ Ma detrital zircon peak (Fig. 10a) correlates with the widespread rift magmatism of the Angola block, western Kalahari and Dom Feliciano basement inliers (see below). The Nico Pérez terrane is also considered as derived from the western edge of the Angola block during the $c$. 780 Ma Neoproterozoic rifting (Fig. 11). The stacking of lithotectonic assemblages of the Nico Pérez terrane, which includes Archaean, Palaeoproterozoic, Mesoproterozoic and Neoproterozoic units, took place during the Neoproterozoic to early Palaeozoic Brasiliano/PanAfrican oblique collision (Mallmann et al., 2007); this corresponds to the southwestern sector of the Adamastor Orogen of Goscombe and Gray (2008). To describe the initial rifting scenario, a new term Adamastoria is introduced to include all the continental terrane fragments formed after the opening of the Northern Adamastor Ocean, as shown in Fig. 11. The possibility that the basement inliers of the Dom Feliciano belt, such as the Punta del Este terrane and the Encantadas complex (Leite et al., 2000; Saalmann et al., 2010 and references therein), as well as the exotic Luis Alves microplate (Fig. 2; Basei et al., 2009) and the Betara region in southwestern Brazil (Siga et al., 2011) were all part of the same collage is a hypothesis well worth testing in future studies.

\subsection{Relationship to the Dom Feliciano belt}

The detrital age pattern of the Schist Belt presented here (Fig. 10b) is a composite result that includes data from the three main segments of the belt: Brusque, Porongos and Lavalleja (Fig. 3a) (Basei et al., 2008a). Data from the metavolcano-sedimentary Porongos Group contain a Neoproterozoic fraction indicating a post-620 Ma depositional age for these rocks (Basei et al., 2008a), which conflicts with the c. $780 \mathrm{Ma}$ age inferred for the succession (Saalmann et al., 2010). Nevertheless, this composite Schist Belt detrital pattern is important because it shows Mesoproterozoic (1200 and $1500 \mathrm{Ma}$ ), Late Palaeoproterozoic (1800-1900 Ma) and Archaean zircon populations, which are also present in the Punta Mogotes Formation (Fig. 10a, b). The 840-740 Ma detrital interval is not conspicuous as in the Punta Mogotes Formation, that might be related with the reduced number of zircons analyzed per sample ( $\mathrm{n}=20$, Basei et al., 2008a).

Until recently, the paucity of early Neoproterozoic ages in the Dom Feliciano belt prevented comparison with the widespread rifting event of the Angola block and western Kalahari sectors (e.g., Kröner et al., 2004). This has been largely overcome by new geochronological data for Neoproterozoic extensional magmatism in the Dom Feliciano Schist Belt (Oyhantçabal et al., 2009; Saalmann et al., 2010 and references therein). Most of these magmatic rocks are felsic; some 
show intraplate signatures ( $838 \pm 9 \mathrm{Ma}$, mylonitic A-type granite, Brusque Group, Basei et al., 2008b), but many are acid metavolcanic rocks intercalated with the metasedimentary rocks of the Schist Belt $(783 \pm 6 \mathrm{Ma}$ to $789 \pm 7 \mathrm{Ma}$, Porcher et al., 1999; Chemale, 2000; Saalmann et al., 2010). This volcanism shows Palaeoproterozoic to Neoarchaean $\mathrm{Nd}_{\mathrm{DM}}$ model ages as well as negative $\varepsilon \mathrm{Nd}(\mathrm{t}=780 \mathrm{Ma})$, suggesting re-melting of the basement during the extensional basin formation (Chemale, 2000; Saalmann et al., 2007, 2010).

Basementinliers of the Dom Feliciano Belt, such as the Punta del Este Terrane (Fig. 3a), contain $761 \pm 8 \mathrm{Ma}$ to $776 \pm 12 \mathrm{Ma}$ orthogneisses, with inherited 1.94-2.06 Ga and 1.07 zircon cores (U-Pb SHRIMP, Hartmann et al., 2002a; Oyhantçabal et al., 2009; Basei et al., 2010), inferred to be rift-related and correlated with the Coastal terrane of the Kaoko belt (Goscombe et al., 2005; Goscombe and Gray, 2007, 2008; Oyhantçabal et al., 2009) or the Namaqua complex of the Gariep Belt (Basei et al., 2010). As noted above, 740-840 Ma igneous detrital zircon grains of the Punta Mogotes Formation have negative $\varepsilon \mathrm{Hf}_{\mathrm{t}}$, positive $\delta^{18} \mathrm{O}$ and Palaeoproterozoic to Archaean $\mathrm{Hf}_{\mathrm{DM}}$ model ages, suggesting that the early Neoproterozoic rocks were formed by melting of old crustal rocks (Figs. 7, 8), as were the felsic rocks of the Dom Feliciano Schist Belt. We conclude that the Punta Mogotes Formation is probably one of the southemmost exposures of the Schist Belt.

Assuming that the Mar del Plata terrane (Fig. 3b) belongs to the southernmost sector of the Dom Feliciano belt, the W-E spatial distribution of units observed along the entire length of the latter (Fig. 3a) would be expected to continue off-shore, east of Mar del Plata. It is therefore predicted that the continental shelf at $38^{\circ} \mathrm{S}$ is composed, from West to East, by the Río de la Plata craton, a southern extension of the Sarandi del Yí + Sierra Ballena shear zones, the Schist Belt (Punta Mogotes Formation, Mar del Plata terrane), a southern extension of the Granite Belt, and probably equivalents of the Punta del Este and Rocha terranes (Fig. 3a). The Rocha Group low-grade metasediments have Neoproterozoic (Brasiliano) detrital zircon age peaks, and are therefore younger, but also show detrital patterns indicating derivation from the basement of the Gariep belt, i.e., the Namaqua complex and the Richtersveld terrane. The Rocha Group is correlated with the Oranjemund Group of the Gariep belt (youngest detrital zircon c. $610 \mathrm{Ma}$, Basei et al., 2005), whose deposition preceded the eastward transport of the oceanic rocks of the Marmora terrane ca. $575 \mathrm{Ma}$ (Frimmel et al., 2010 and references therein). For all these reasons, the Punta Mogotes Formation cannot be correlated with the Rocha Group, contrary to suggestions by Bossi and Cingolani (2009) and Cingolani (2010).

A test of the above hypothesis on the composition of the continental shelf is provided by the detrital zircon patterns of the Late Cambrian to Ordovician/Silurian (?) Balcarce Formation that covers the fault between the Río de la Plata craton and the Mar del Plata terrane (Figs. 3b, 7). All samples show Mesoproterozoic (c. 1030-1150 Ma) and Late Palaeoproterozoic (c. 1700-2000 Ma) peaks, similar to the Namaqua and Richtersveld terrane of the Gariep belt (Figs. 7, 10c, d). In contrast to the Punta Mogotes Formation (Fig. 6), the Balcarce sediments show (i) typical Brasiliano/Pan-African components, (ii) absence of Mesoproterozoic components in the range 1420-1560 Ma. This indicates that the Balcarce Formation is not only younger, but that its sources were different; suitable candidates are the Dom Feliciano Granite belt and the basement of the Gariep belt.

\subsection{A geodynamic scenario}

Detrital zircons age patterns from the Punta Mogotes borehole provide important new constraints on the role played by the Río de la Plata craton at the time of SW Gondwana amalgamation in the late Neoproterozoic to the early Cambrian. We present here a new geotectonic model for the overall Brasiliano/Pan-African orogenic realm with emphasis on the Rio de la Plata craton (see Fig. 12). The model combines our results with those of recent contributions (e.g., Goscombe and Gray, 2008; Gaucher et al., 2009; Frimmel et al., 2010; Oyhantçabal et al., 2010b; Saalmann et al., 2010).

The starting point is that the ages of basement complexes and zircon detrital patterns of Neoproterozoic successions in Uruguay, Argentina and southeastern Brazil are remarkably similar to those of the Angola block, suggesting that they were conjugate margins of the northern Adamastor Ocean. Opening of this ocean took place between 740 and $840 \mathrm{Ma}$ (Figs. 10, 12a) probably along the NW-SE rifted arm of a triple point west of the present Damara orogen (Goscombe et al., 2005 and references therein). A second NE-SW rifted arm developed along the edge of the Kalahari craton (Jacobs et al., 2008) (Fig. 11). The continental mass that drifted away from both the Angola block and northwestemmost Kalahari craton is called here Adamastoria (see above).

At 700-750 Ma another oceanic terrane existed west of Adamastoria. It is called the São Gabriel Ocean and involved a juvenile intraoceanic arc (São Gabriel juvenile block, Hartmann et al., 2011 and references therein) (Figs. 3a and 12a). The arc was accreted at c. $700 \mathrm{Ma}$ to the Paranapanema block soon after the São Gabriel Ocean closed, leading to docking of Adamastoria and the Paranapanema block (Fig. 12b).

Closure of the northern Adamastor Ocean started at c. $680 \mathrm{Ma}$ (Gray et al., 2006) and involved oblique displacement of the now welded Paranapanema and Adamastoria block relative to the Angola block. Sinistral collision took place between 600 and $640 \mathrm{Ma}$, producing a doubly-vergent orogenic belt with eastward thrusting and folding in the Coastal terrane of the Kaoko belt and westward thrusting and folding in the Dom Feliciano belt, with a magmatic arc in between (Goscombe and Gray, 2007, 2008) (Fig. 12b). The clockwise P-T path inferred for the mafic granulites and migmatites of the Punta del Este terrane (Dom Feliciano belt), is consistent with a history of crustal thickening (7-10 kbar) followed by rapid exhumation in the 600-650 Ma interval (Gross et al., 2009). This metamorphic event has been correlated with a similar one observed in the Kaoko belt (Gross et al., 2009; Oyhantçabal et al., 2009). Deformation subsequent to collision in the Kaoko and Dom Feliciano belts at 580-550 Ma was accommodated by sinistral transpression recorded in shear zones (Oyhantçabal et al., 2010b) (Fig. 12b). This suggests that the Damara belt was bounded to the west by transcurrent sinistral zones (Goscombe and Gray, 2008).

NW-directed indentation of the Kalahari craton led to progressive closure of the southern Adamastor Ocean. The estimated c. 580 Ma age of left-lateral displacement of the Río de la Plata craton along the SYSZ shear zone is probably coincident with the onset of subduction of the southern Adamastor Ocean, with simultaneous subduction-related metamorphism at c. $580 \mathrm{Ma}$ in the Marmora terrane of the Gariep belt (Frimmel and Frank, 1998; Rozendaal et al., 1999). The fact that the SYSZ megashear juxtaposes terranes affected by the Brasiliano/Pan-African orogeny and the un-rejuvenated Río de la Plata craton suggests that tectonism after $580 \mathrm{Ma}$ in the southem Adamastor realm, i.e., to the east of the Punta del Este terrane (Figs. 3, 11b), constituted a different orogeny. Closure of the southern Adamastor Ocean at c. $545 \mathrm{Ma}$ (Fig. 12c) produced the Gariep belt and migrated southward into the Saldanian belt, which records orogenic ensialic arc magmatism (the Cape Granite Suite) until c. $520 \mathrm{Ma}$.

Subduction of the southern Adamastor Ocean was towards the northwest whereas folding and thrusting in the Gariep was opposite, i.e., towards the east and southeast (Frimmel and Frank, 1998), implying that a magmatic arc existed to the west of the southern Adamastor suture, the latter indicated by the Marmora terrane in the Gariep belt. This arc might correspond to the Cape Granite Suite intruding the Tygerberg and Swartland terranes in the Saldania belt (Chemale et al., 2010). The juvenile Bridgetown Formation separating the Swartland and Boland terranes might then correspond to the suture (Rozendaal et al., 1999).

The basement rocks of the Sierra de la Ventana, which is the southern boundary of the Rio de la Plata craton, include Dom Feliciano age (570- 


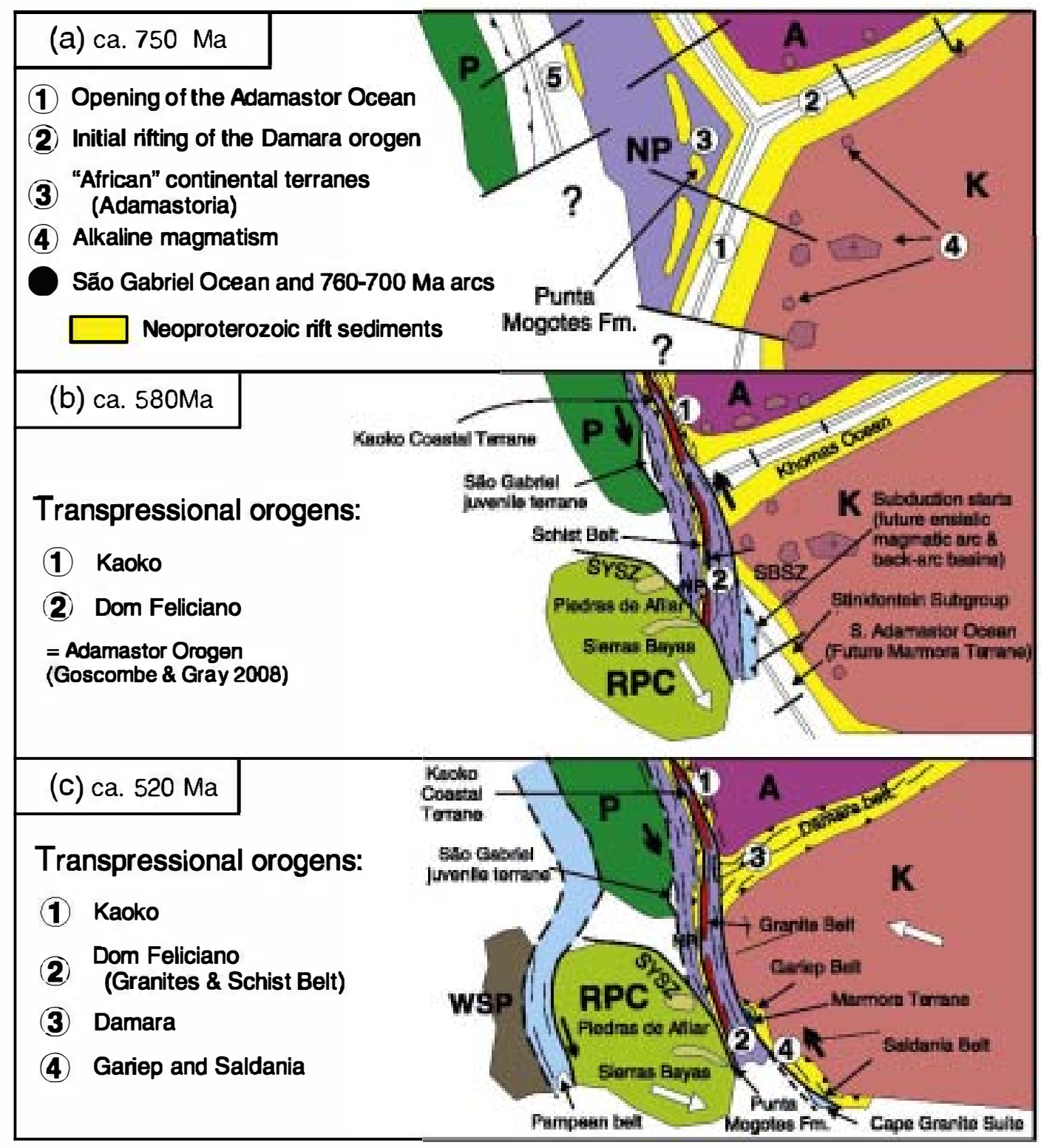

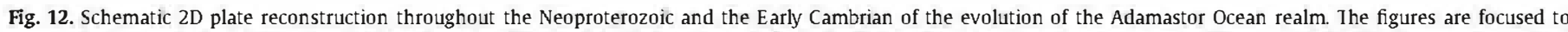

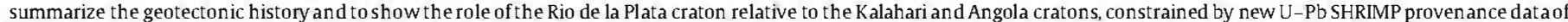

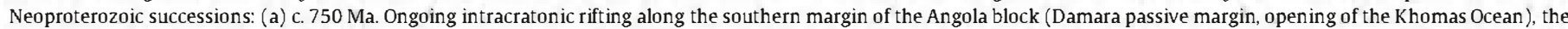

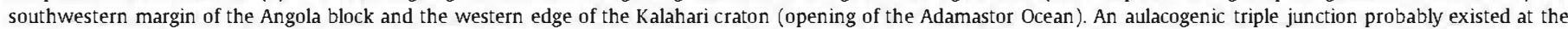

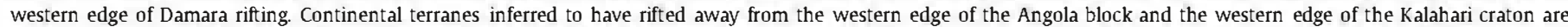

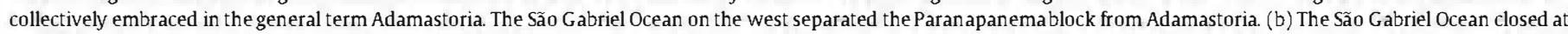

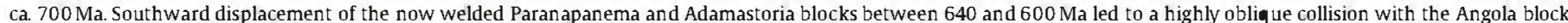

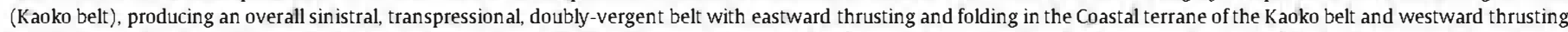

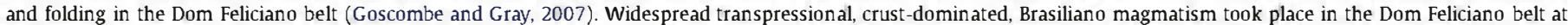

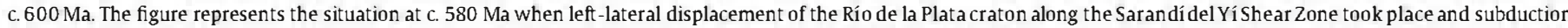

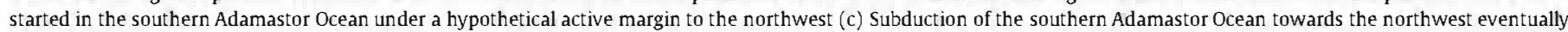

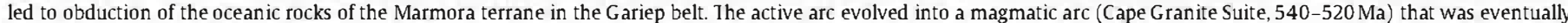

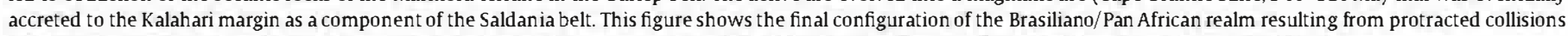
between cratons for over 300 Ma. Cratons and continental blocks: A, Angola block; K, Kalahari; RPC, Río de la Plata; LA, Luiz Alves. See text for references.

$610 \mathrm{Ma}$ ) crustal granites, 530-520 Ma calc-alkaline and A-type granites and $510 \mathrm{Ma}$ peralkaline rhyolites (Rapela et al., 2003; Tohver et al., 2011). The granitic suite of this basement has been correlated with the Cape Granite Suite in southern Africa (Rapela et al, 2003). As a working hypothesis, it is considered here that the basement of the Sierra de la Ventana basement was probably dextrally transported from the Saldania Belt to its present position at some moment between of the end of orogenic magmatism and the age of the first overlying sediments that contain Río de la Plata-sourced zircons (La Mascota Formation, Late Cambrian, RJ. Pankhurst, unpublished).
Two different orogenies are thus envisaged within the overall Brasiliano/Pan-African orogeny: the Dom Feliciano-Kaoko orogeny (regarded as part of a more extensive Adamastor orogen by Goscombe and Gray, 2008) and the Gariep-Saldania orogeny. The latter was partly coincident with the Damara orogeny. The metamorphic peak in the Punta del Este terrane and the Kaoko belt were roughly coeval at c. $650 \mathrm{Ma}$ (Goscombe et al., 2005; Gray et al., 2006; Gross et al., 2009; Oyhantçabal etal, 2009), whereas those in the Gariep and Saldania belts in southwestem Africa (Fig. 11) are considerable younger (c. $545 \mathrm{Ma}$; Frimmel and Frank, 1998; Armstrong et al., 1998; Da Silva et al, 2000). 
The Río de la Plata craton thus remains a large craton that was tectonically emplaced against the Dom Feliciano-Gariep belt in Ediacaran times, i.e., after the main orogenic events (folding, thrusting, metamorphism and magmatism) but very close to the onset of the Gariep-Saldania orogeny. The craton was derived from an unknown region in the west and carried a sedimentary cover older than $c$ $580 \mathrm{Ma}$, with detrital zircon sources different from those of the Adamastoria Neoproterozoic sediments.

Note that the model described above differs in several key issues from the Arachania arc/terrane model of Gaucher et al. (2009) and Frimmel et al. (2010). The latter considered that the Western Kalahari and the Río de la Plata cratons were juxtaposed, and started to rift apart at 770-720 Ma. They also enlarge the Río de la Plata craton by including terranes here considered as derived from either the Angola block or from basement areas affected by the $770-720 \mathrm{Ma}$ rifting between northwestern Kalahari craton and Adamastoria.

\section{Conclusions}

The Río de la Plata craton at the latitude of the Tandilia belt $\left(\right.$ c. $\left.38^{\circ} \mathrm{S}\right)$ is separated by an important fault from a distinct continental terrane (Mar del Plata terrane).

On all sides the boundaries of the Río de la Plata craton are transcurrent faults of late Neoproterozoic to early Palaeozoic age.

The Precambrian Punta Mogotes Formation of the Mar del Plata terrane is correlated with the Schist Belt of the Dom Feliciano belt of south-eastern Brazil and Uruguay.

740-840 Ma detrital zircons of the Punta Mogotes formation show negative $\varepsilon \mathrm{Hf}_{\mathrm{t}}$ values and $\delta^{18} \mathrm{O}$ values $>6.5 \%$ o suggesting derivation by melting of Palaeoproterozoic to Archaean crust. Rocks forming the offshore continental platform at $c .38^{\circ} \mathrm{S}$ are probably part of the Dom Feliciano belt.

The detrital zircon pattern of the Punta Mogotes Formation is compatible with a source for the Mar del Plata terrane close to the Angola block, from which it rifted away during opening of the northern Adamastor Ocean at 760-780 Ma. Other continental terranes in Uruguay, such as the Nico Pérez, Encantadas and Punta del Este terranes, and others in southeastern Brazil could have been formed in a similar way. All are embraced here within the Adamastoria continent.

The formation of West Gondwanaincluded at least two major overall transpressional orogenies: the Kaoko-Dom Feliciano (580-680 Ma) and the Gariep-Saldania (520-580 Ma). Siliciclastic platform sediments such as the Balcarce Formation in the Tandilia belt and the Table Mountain Group in the western Cape region of southern Africa, were laid down after the amalgamation of SW Gondwana.

Supplementary materials related to this article can be found online at doi:10.1016/j.gr.2011.05.001.

\section{Acknowledgments}

Financial support for this paper was provided by Argentine public grants CONICET PIP 02340, FONCYT PICI 2006-1009, and Spanish grants CGL2009-07984 and GR58/08 UCM-Santander. Federico Isla (University of Mar del Plata-CONICET) kindly provided the sample PMOG, while SEGEMAR allowed the study of the Punta Mogotes borehole. Norberto Malumian (SEGEMAR-CONICE $\Gamma$ ) is specially thanked for his help with the drill core samples. José Kostadinoff and Pedro Oyhantçabal made useful comments on the geophysical anomalies in the Mar del Plata-Balcarce area and the mylonitic belts of southern Uruguay respectively. A. Benialgo helped with the digital images and $A$. Metetiero with the drawing of some figures. Eric Tohver and an anonymous reviewer are thanked for their constructive suggestions.

\section{References}

Armstrong, R., de Wit, M.J., Reid, D., York, D., Zartman, R., 1998. Cape Town's Table Mountain reveals rapid Pan-African uplift of its basement rocks. Journal of African Earth Sciences 27, 10-11.

Baldo, E., Casquet, C., Pankhurst, R J., Galindo, C., Rapela, C.W., Fanning, C.M., Dahle uist, J.A., Murra, J., 2006. Neoproterozoic A-type granitic magmatism in the Western Sierras Pampeanas (Argentina): evidence for Rodinia break-up along a protoIapetus rift? Terranova 18, 388-394.

Basei, M.A.S., Frimmel, H.E., Nutman, A.P., Preciozzi, F., Jacob, J., 2005. A connection between the Neoproterozoic Dom Feliciano (Brazil/Uruguay) and Gariep study. Precambrian Research 139, 195-221.

Basei, M.A.S., Frimmel, H.E, Nutman, A.P., Preciozzi, F., 2008a. West Gondwana amalgamation based on detrital zircon ages from Neoproterozoic Ribeira and Dom Feliciano belts of South America and comparison with coeval sequences from SW Africa. In: Pankhurst, R.J., Trouw, R.A., Brito Neves, B.B., de Wit, MJ. (Eds.), West Gondwana: Pre-Cenozoic Correlations Across the South Atlantic Region. Geological Society, 294. Special Publications, London, pp. 239-256.

Basei, M.A.S., Nutman, A., Grasso, C.B., Vlach, S., Siga Jr., O., Osako, L, 2008b. The Cryogenian rift-related granitogenesis of the Dom Feliciano Belt, Southern Brazil Abstract volume, 4th international SHRIMP workshop. VSEGEI Press, Sain Petersburg, Russia, pp. 24-26.

Basei, M.A.S., Nutman, A., Siga Jr., O., Passarelli, C.R., Drukas, C.O., 2009. The evolution and tectonic setting of the Luis Alves microplate of Southeastern Brazil: an exotic terrane during the assembly of Western Gondwana. In: Gaucher, C, Sial, A.N., Halverson, G.P., Frimmel, H.E. (Eds.), Neoproterozoic-Cambrian Tectonics, Global Change and Evolution: A Focus on Southwestern Gondwana. Developments in Precambrian Geology, 16. Elsevier, pp. 273-291.

Basei, M.A.S., Peel, E., Sánchez Bettuchi, L, Preciozzi, F., Nutman, A.P., 2010. The basement of the Punta del Este Terrane (Uruguay): an African Mesoproterozoic fragment at the eastern border of the South American Río de la Plata craton. International Journal of Earth Sciences 100, 289-304.

Becker, T., Garoeb, H., Iedru, P., Milesi, J.P., 2005. The Mesoproterozoic event within the Rehoboth Basement Inlier of Namibia: review and new aspects of stratigraphy, geochemistry, structure and plate tectonic setting. South African Journal of Geology $108,465-492$

Becker, T., Schreiber, U., Kampunzu, A.B., Armstrong, R, 2006. Mesoproterozoic rocks of Namibia and their plate tectonic setting. Journal of African Earth Sciences 46, $112-140$.

Booker, J.R., Favetto, A., Pomposiello, M.C., 2004. Low electrical resistivity associated with plunging of the Nazca flat slab beneath Argentina. Nature 429, 399-403.

Bossi, J., Cingolani, C., 2009. Extension and general evolution ofthe Río de la Plata craton. In: Gaucher, G., Sial, A.N., Halverson, G.P., Frimmel, H.E. (Eds.), Neoproterozoic-Cambrian Tectonics, Global Change and Evolution: A Focus on Southwestern Gondwana. Developments in Precambrian Geology, 16. Elsevier, pp. 73-85.

Bouvier, A., Vervoort, J.D., Patchett, P.J., 2008. The Lu-Hf and Sm-Nd isotopic composition of ClIUR: constraints from unequilibrated chondrites and implications for the bulk composition of terrestrial planets. Earth and Planetary Science Letters 273, 48-57.

Cawood, P.A, Buchan, C, 2007. Linking accretionary orogenesis with supercontinent assembly. Earth-Science Reviews 82, 217-256.

Chemale Jr., F., 2000. Evolução geológica do Escudo Sul-riograndense. In: Holtz, M., De Ros, L.F. (Eds.), Geologia do Rio Grande do SuI. CIGO/UFRGS. Porto Alegre, Brazil pp. $13-52$.

ChemaleJr., F., Scheeepers, R., Gresse, P.G., Van Schmus, W.R., 2010. Geochronology and sources of late Neoproterozoic to Cambran granites of the Saldania Belt. International Journal of Earth Science 100, 431-444.

Cherniooff, C.J., Zappettini, E.O., Santosh,J.O.S., Godeas, MC., Belousova, E., McNaughton, N.J., 2011. Identification and isotopic studies of Early Cambrian magmatism (El Carancho Igneous Complex) at the boundary between Pampia terrane and the Rio de la Plata craton, La Pampa province, Argentina. Gondwana Research. doi:10.1016/j. gr.2011.04.007

Cingolani, C.A, 2010. The Tandilia System of Argentina as a southern extension of the Río de la Plata craton: an overview. International Journal of Earth Sciences 100, 221-242.

Cingolani, C.A., Bonhomme, M.G., 1982. Geochronology of La Tinta Upper Proterozoic Sedimentary Rocks, Argentina. Precambrian Research 18, 119-132

Cingolani, C.A., Santos, J.O.S., McNaughton, N.J., Hartmann, LA., 2005. Geocronología U-Pb SHRIMP sobre circones del granitoide Montecristo, Tandil, provincial de Buenos Aires, Argentina 16th Congreso Geológico Argentino, Actas, I, pp. 299-302.

Cingolani, C.A., Uriz, N.J., Chemale Jr., F., 2010. New Detrital Zircon U-Pb Ages on Neoproterozoic Tandilia Sequences, Río de la Plata Craton. Argentina. VII South American Symposium on Isotope Geology, Brasilia. 5-8.

Colombo, F., Baldo, E.G., Casquet, C., Pankhurst, R.J., Galindo, C., Rapela, C.W., Dahlquist, J.A., Fanning, C. J., 2009. A-type magmatism in the sierras ofMaz and Espinal: a new record of Rodinia break-up in the Western Sierras Pampeanas of Argentina. Precambrian Research $175,77-86$.

Da Silva, L.C., Gresse, P.G., Scheepers, R., McNaughton, N.J., Hartmann, L.A., Fletcher, I., 2000. U-Pb SHRIMP and Sm-Nd age constraints on the timing and sources of the Pan-African Cape Granite Suite, South Africa. Journal of African Earth Sciences 30, 795-815.

Dalla Salda, L., Iñiguez, A.M., 1979. La Tinta, Precámbrico y Paleozoico de Buenos Aires 7th Congreso Geológico Argentino, Actas I, pp. 539-550.

Dalziel, I.W.D., 1997. Neoproterozoic-Paleozoic geography and tectonics: review, hypothesis, environmental speculation. Geological Society of America Bulletin 108 $16-42$ 
Dürr, S.B., Dingeldey, D.P. 1996. The Kaoko belt (Namibia): part of a late Neoproterozoic continental-scale strike-slip system. Journal of Geology 24, 503-506.

Eglington, B.M., 2006. Evolution of the Namaqua-Natal Belt, southern Africa-A geochronological and isotope geochemical review. Journal of Af rican Earth Sciences 46, 93-111.

Flowerdew., M.J., Millar, LL, Curtis, M.L, Vaughan, A.P.M., Horstwood, A.P.M., Whitehouse, M.J., Fanning, C.M., 2007. Combined U-Pb geochronology and Hf isotope geochemistry of detrital zircons f rom early Paleozoic sedimentary rocks, EllsworthWhitmore Mountains block, Antarctica. Geological Society of America Bulletin 119 275-288.

Font, E., Ponte Neto, C.F., Ernesto, M., 2011. Paleomagnetism and Rock Magnetism of the Neoproterozoic Itjai Basin of the Rio de la Plata craton (Brazil): Cambrian to Cretaceous widespread remagnetization of South American. Gondwana Research. doi:10.1016/j.gr.2011.04.005

Frimmel, H.E., 1995. Metamorphic evolution of the Gariep Belt. South African Journal of Geology 98, 176-190.

Frimmel, H.E., 2000. The Pan-African Gariep Belt in southwestern Namibia and Western South Africa. In: Miller, R.McG. (Ed.), Communications of the Geological Survey of Namibia, 12, pp. 197-209.

Frimmel, H.E., Frank, W., 1998. Neoproterozoic tectono-thermal evolution of the Gariep Belt and its basement, Namibia/South Africa. Precambrian Research 90, 1-28.

Frimmel, H.E., Zartman, R.E., Späth, A., 2001. The Richstersveld Igneous Complex, South Africa: U-Pb zircon and geochemical evidence for the beginning of the Neoproterozoic continental break-up. Journal of Geology 109, 493-508.

Frimmel, H.E., Basei, M.S., Gaucher, C., 2010. Neoproterozoic geodynamic evolution of SW-Gondwana: a southern African perspective. International Journal of Earth Science $100,323-354$

Gaucher, C., Finney, S.C., Poiré, D.G., Valencia, V.A., Grove, M., Blanco, G., Pamoukaghlian, K., Gómez Peral, L, 2008. Detrital zircon ages of Neoproterozoic sedimentary successions in Uruguay and Argentina: insights into the geological evolution of the Río de la Plata Craton. Precambrian Research 167, 150-170.

Gaucher, C., Frimmel, H.E., Germs, G.J.B., 2009. Tectonic events and palaeogeographic evolution of southwestern Gondwana in the Neoproterozoic and Cambrian. In: Gaucher, C., Sial, A.N., Halverson, G.P., Frimmel, H.E. (Eds.), NeoproterozoicCambrian Tectonics, Global Change and Evolution: A Focus on Southwestern Gondwana. Developments in Precambrian Geology, 16. Elsevier, pp. 295-316.

Gaucher, C., Frei, R., Chemale Jr., F., Frei, D., Bossi, J., Martínez, Gabriela, Chiglino, L. Cernuschi, F., 2010. Mesoproterozoic evolution of the Río de la Plata Craton in Uruguay: at the heart of Rodinia? International Journal of Earth Science 100, 273-288.

Gómez Peral, LE., Poiré, D.G., Strauss, H., Zimmermann, U., 2007. Chemostratigraphy and diagenetic constraints on Neoproterozoic carbonate successions from the Sierras Bayas Group, Tandilia System, Argentina. Chemical Geology 237, 127-146.

Goscombe, B., Gray, D.R., 2007. The Coastal Terrane of the Kaoko Belt, Namibia: outboard arc-terrane and tectonic significance. Precambrian Research 155, 139-158.

Goscombe, B., Gray, D.R., 2008. Structure and strain variation at mid-crustal levels in a transpressional orogen: a review of Kaoko Belt structure and the character of West Gondwana amalgamation and dispersal. Gondwana Research 13, 45-85.

Goscombe, B., Gray, D., Armstrong, R., Foster, D.A., Vogl,J., 2005. Eventgeochronology of the Pan-African Kaoko Belt, Namibia. Precambrian Research 140,1-41.

Gray, D.R., Foster, D.A, Goscombe, B., Passchier, C.W., Trouw, R.A.J., 2006. 40Ar/39Ar thermochronology of the Pan-African Damara orogen, Namibia, with implications for tectonothermal and geodynamic evolution. Precambrian Research 150, 49-72.

Gray, G.R., Foster, D.A., Meert, J.G., Gosoombe, B.D., Armstrong, R., Trouw, R.A.J., Passchier, C.W., 2008. A Damara orogen perspective on the assembly of southwestern Gondwana. In: Pankhurst, R.J., Trouw, R.A.J., Brito Neves, B.B., De Wit, M.J. (Eds.), West Gondwana: Pre-Cenozoic Correlations Across the South Atlantic Region. Geological Society, 294. Special Publications, Iondon, pp. 257-278.

Gross, A.O.M.S., Droop, G.T.R., Porcher, C.C., Fernandes, L.A.D., 2009. Petrology and thermobarometry of mafic granulites and migmatites from the Chafalote Metamorphic Suite: New insights into the Neoproterozoic P-T evolution of the Uruguayan-Sul-Rio-Grandense shield. Precambrian Research 170, 157-174.

Hälbich, LW., Alchin, D.J., 1995. The Gariep Belt; stratigraphical-structural evidence for obliquely transformed grabens and back-folded thrust-stacks in a combined thickskin and thin skin structural setting. Journal of African Earth Sciences 21, 9-33.

Hanson, R.E. 2003. Proterozoic East Gondwana: supercontinent assembly and breakup. In: Yoshida, M., Windley, B.F., Dasgupta, S. (Eds.), Proterozoic Geochronology and Tectonic Evolution of Southern Africa. Geological Society, 206. Special Publications, London, pp. 427-463.

Hartmann, LA., Santos,J.O.S., Bossi,J., Campal, N., Schipilov, A., McNaughton, N.J., 2002a Zircon and titanite U-Pb SHRIMP geochronology of Neoproterozoic felsic magmatism on the eastern border of the Río de la Plata craton, Uruguay. Journal of South American Earth Sciences 15, 229-236.

Hartmann, LA., Santos, J.O.S., Cingolani, C.A. McNaughton, N.J., 2002b. Two Palaeoproterozoic orogenies in the evolution of the Tandilia Belt, Buenos Aires, as evidenced by zircon U-Pb SHRIMP geochronology. International Geology Review 44, 528-543.

Hartmann, LA., Philipp, R.P., Santos, J.O.S., McNaughton, N.J., 2011. Time frame of 753-680 Ma juvenile accretion during the Säo Gabriel orogeny, southern Brazilian Shield. Gondwana Research 19, 84-99.

Hartnady, C.J., Joubert, P., Stowe, C., 1985. Proterozoic crustal evolution in southwestern Africa. Episodes 8, 236-244.

Heilbron, M., Valeriano, C.M., Tassinari, C.C.G., Almeida, J., Tupinambá, M., Siga Jr., O., Trouw, R., 2008. Correlation of Neoproterozoic terranes between the Ribeira Belt, SE Brazil and its African counterpart: comparative tectonic evolution and open questions. In: Pankhurst, R.J., Trouw, R.A., Brito Neves, B.B., de Wit, M.J. (Eds.), West
Gondwana: Pre-Cenozoic Correlations Across the South Atlantic Region. Geological Society, 294. Special Publications, Iondon, pp. 211-237.

Hoffman, P.F., Hawkins, D.P., Isachsen, C.E., Bowring, S.A, 1996. Precise U-Pb zircon ages for early Damaran magmatism in the Summas Mountains and Welwitschia Inlier, northern Damara Belt, Namibia. Communications of the Geological Survey of Namibia 11, 47-52.

Iannizzotto, N.F, 2010. Estudio petrologico - geoquímico e implicancias tectónicas del arco magmático de Sierra Norte - Ambargasta en su sector mas austral. Universidad Nacional de Ia Plata, Facultad de Ciencias Naturales y Museo, (unpublished doctoral thesis, 327p)

Iñiguez, A.M., 1999. La cobertura sedimentaria de Tandilia. In: Caminos, R. (Ed.) GeologíaArgentina. Servicio Geológico Minero Argentino: Anales, 29, pp. 101-106.

Jacobs, J., Pisarevsky, S., Thomas, R.J., Becker, T., 2008. The Kalahari Craton during the assembly and dispersal of Rodinia. Precambrian Research 160, 142-158.

Johnson, S.P., Rivers, T., De Waele, B., 2005. A review of the Mesoproterozoic to early Palaeozoic magmatic and tectonothermal history of south-central Africa: implications for Rodinia and Gondwana. Journal of the Geological Society, Iondon 162, 433-450.

Konopásek, J.K., Kröner, S., Kitt, S.L., Passchier, C.W., Kröner, A., 2005. Oblique collision and evolution of large-scale transcurrent shear zones in the Kaoko Belt, NW Namibia. Precambrian Research 236, 139-157.

Konopásek, J.K., Tajčmanová, L, Ulrich, S., Kitt, S.L, 2008. Neoproterozoic igneous complex emplaced along major tectonic boundary in the Kaoko Belt (NW Nambia): ion probe and LA-ICP-MS dating of magmatic and metamorphic zircons. Journal of the Geological Society, London 165, 153-165.

Kostadinoff, J., 1995. Geofísica de las Sierras de TandiL Universidad Nacional de Ia Plata, Facultad de Ciencias Astronómicas y Geofisicas, La Plata, Argentina (unpublished doctoral thesis), $178 \mathrm{pp}$.

Kretz, R., 1983. Symbols for rock-forming minerals. American Mineralogist 68, 277-279.

Kröner, S., Konopásek, J., Kröner, A., Passchier, C.W., Poller, U., Wingate, M.T.D. Hofmann, K.H., 2004. U-Pb and $\mathrm{Pb}-\mathrm{Pb}$ zircon ages for metamorphic rocks in the Kaoko Belt of Northwestern Namibia: a Palaeo- to Mesproterozoic basement reworked during the Pan-African orogeny. South African Journal of Geology 107 , 455-476.

Leite, J.A.D., Hartmann, LA., Fernandes, L.A.D., McNaughton, N.J., Soliani Jr., Ê., Koester, E., Santos, J.O.S., Vasconcellos, M.A.Z., 2000. Zircon U-Pb SHRIMP dating of gneissic basement of the Dom Feliciano Belt, southernmost Brazil. Journal of South American Earth Sciences 13, 739-750.

Li, ZX, Bogdanova, S.V., Collins, A.S., Davidson,A.S., De Waele, B.,Emst, R.E., Fitzsimons, LC.W., Fuck, R.A, Gladkochub, D.P., Jacobs, J., Karlstrom, K.E., Lu, S., Natapov, L.M., Pease, V. Pisarevsky, S.A, Thrane, K.V., Vernikovsky, V., 2008. Assembly, configuration, and breakup history of Rodinia: A synthesis. Precambrian Research 160, 179-210.

Ludwig, K.R., 2001. SQUID 1.02, A User's Manual; Berkeley Geochronology Center Special Publication No. 2, 2455 Ridge Road, Berkeley, CA 94709, US.

Ludwig, K.R., 2003. Isoplot/Ex version 3.0: A geochronological toolkit for Microsoft Excel. Berkeley Geochronology Center Special Publication No. 4, 2455 Ridge Road, Berkeley CA 94709, USA.

Mallmann, G., Chemale Jr., F., Avila, J.N., Kawashita, K., Armstrong, R.A, 2007. Isotope geochemistry of the Nico PérezTerrane, Río de la Plata Craton, Uruguay. Gondwana Research 12, 489-508.

Marchese, H.G., Di Paola, E.C., 1975. Reinterpretación estratigráfica de la Perforación Punta Mogotes $\mathrm{N}^{\bullet} 1$, Provincia de Buenos Aires, República Argentina. Revista de la Asociación Geológica Argentina 30, 44-52.

Master, S., 2009. Neoproterozoic CARCs in the Damara-Lufilian-Zambezi and Ubendian belts and the Western Rift Rise- relics of Rodinia fragmentation at $750 \pm 50 \mathrm{Ma}$. Out of Africa Conference, Witwatersrand University, Johannesburg, 16-18 November 2009. www.geodynamics.no/outofafrica/pdfs/Master-outofafrica.pdf.

Evolution of the Damara orogen of south west Africa/Namibia. National Geodynamics Programme. In: Miller, R.McG. (Ed.), Geological Society of South Africa Special Publications, 11

Munizaga, F., Maksaev, V., Fanning, C.M., Giglio, S., Yaxley, G., Tassinari, C, 2008. Late Paleozoic-Early Triassic magmatism on the western margin of Gondwana: Collahuasi area, Northern Chile. Gondwana Research 13, 407-427.

Newstead, B.L, Foster, D.A, Goscombe, B., Mueller, P.A, 2009. Crustal formation and recycling during supercontinent cycles: evidence from detrital zircons of the Damara Orogen. GSA Annual Meeting, Portland, Paper. 79-13.

Oyhantaçabal, P., Sánchez-Bettucci, L, Peçoits, E., Aubet, N., Peel, E., Preciossi, F., Basei, M.AS., 2005. XII Congreso Latinoamericano de Geología. Quito, Ecuador (CD-ROM).

Oyhantaçabal, P., Siegesmund, S., Wemmer, K., Freid, R., Layer, P., 2007. Post-collisional transition from calc-alkaline to alkaline magmatism during transcurrent deformation in the southernmost Dom Feliciano Belt (Braziliano-Pan-African, Uruguay). Lithos 98 , 141-159.

Oyhantaçabal, P., Siegesmund, S., Wemmer, K., 2010. The Rio de la Plata Craton: a review of units, boundaries, ages and isotopic signature. International Journal of Earth Science 100, 201-220

Oyhantçabal, P., Siegesmund, S., Wemmer, K., Presnyacov, S., Layer, P., 2009. Geochronological constraintson the evolution of the southern Dom Feliciano Belt (Uruguay). Journal of the Geological Society, London 166, 1075-1084.

Oyhantçabal, P., Siegesmund, S., Wemmer, K., Passchier, CW., 2010a. The transpressional connection between Dom Feliciano and Kaoko Belts at 580-550 Ma. International Journal of Earth Science 100, 379-390.

Oyhantçabal, P., Siegesmund, S., Wemmer, K., Iayer, P., 2010b. The Sierra Ballena Shear Zone in the southernmost Dom Feliciano Belt (Uruguay): evolution, kinematics, and deformation conditions. International Journal of Earth Science 99, 1227-1246. 
Pankhurst, R.J., Ramos, A., Linares, E., 2003. Antiquity and evolution of the Río de la Plata craton in Tandilia, southern Buenos Aires province, Argentina. Journal of South American Earth Sciences 16, 5-13.

Poiré, D.G., Gaucher, C, 2009. Lithostratigraphy. Neoproterozoic-Cambrian evolution of the Río de la Plata Paleocontinent. In: Gaucher, C., Sial, A.N., Halverson, G.P. Frimmel, H.E. (Eds.), Neoproterozoic-Cambrian Tectonics, Global Change and Evolution: A Focus on Southwestern Gondwana. : Developments in Precambrian Geology, 16. Elsevier, pp. 87-101.

Poiré, D.G., Spalletti, L.A., 2005. La cubierta sedimentaria Precámbrica-Paleozoica Inferior del Sistema de Tandilia. In: de Barrio, R.E., Etcheverry, R.O., Caballé, M.F. Llambías, E. (Eds.), Geología y Recursos Minerales de la Provincia de Buenos Aires. $16^{*}$ Congreso Geológico Argentino, Relatorio, 4. La Plata, pp. 51-68.

Porada, H., Berhorst, V., 2000. Towards a new understanding of the Neoproterozoic-early Paleozoic Lufilian and northern Zambezi Belts in Zambia and the Democratic Republic of Congo. Joumal of African Earth Sciences 30, 727-771.

Porcher, C.C., McNaughton, N.J., Leite, J.A.D., Hartmann, L.A., Fernandez, L.A.D. 1999. Idade Shimp em zircão: Vulcanismo ácido do Complexo Metamórfico Porongos. In Simpósio sobre Vulcanismo e Ambientes Asociados, Abstracts, Granado. 110

Rapela, C.W., Pankhurst, R.J., Fanning, C.M., Grecco, L.E., 2003. Basement evolution of the Sierra de la Ventana Fold Belt: new evidence for Cambrian continental rifting along the southern margin of Gondwana. Journal of the Geological Society, London 160 , 613-628.

Rapela, C.W., Pankhurst, R.J., Casquet, C., Fanning, C.M., Baldo, E.G., González-Casado, J.M., Galindo, C., Dahlquist, J., 2007. The Río de la Plata craton and the assembly of SW Gondwana. Earth Science Reviews 83, 49-82.

Reid, D.L., 1979. Age relationships within the mid-Proterozoic Vioolsdrif Batholith, Lower Orange River region. Transactions of the Geological Society of South Africa $82,305-311$.

Reid, D.L., Welke, H.J., Erlank, A.J., Moyes, A., 1987. Geochemistry and mineralization of Proterozoic volcanic suites. In: Pharaoh, T.C., Beckinsale, R.D., Rickard, D. (Eds.), Geological Society, 33. Special Publications, Iondon, pp. 327-346

Robb, L.J., Armstrong, R.A., Waters, D.J., 1999. The history of granulite-facies metamorphism and crustal growth from single zircon $\mathrm{U}-\mathrm{Pb}$ geochronology: Namaqualand, South Africa. Journal of Petrology 40, 1747-1770.

Rozendaal, A., Gresse, P.G., Scheepers, R., Le Roux, J.P., 1999. Neoproterozoic to Early Cambrian crustal evolution of the Pan-African Saldania belt. South Africa Precambrian Research 97, 303-323.

Saalmann, K., Hartmann, L.A., Remus, M.V.D., 2007. The assembly of West Gondwanathe view from the Rio de la Plata craton. In: Linnemann, U., Nance, R.D., Kraft, P. Zulauf, G. (Eds.), The evolution of the Rheic Ocean: From Avalonian-Cadomian Active Margin to Alleghenian-Variscan Collision: Geological Society of America Special Paper, 423, pp. 1-26.

Saalmann, K., Gerdes, A., Lahaye, Y., Hartmann, L.A., Remus, M.V.D., Läufer, A., 2010 Multiple accretion at the eastern margin of the Rio de la Plata craton: the prolonged Brasiliano orogeny in southernmost Brazil. International Journal of Earth Sciences $100,355-378$.

Seth, B., Kröner, A., Mezger, K., Nemchin, A.A., Pidgeon, R.T., Okrush, M., 1998. Archaean to Neoproterozoic magmatic events in the Kaoko belt of NW Namibia and their geodynamic significance. Precambrian Research 92, 341-363.

Seth, B., Armstrong, R.A., Büttner, A., Villa, I.M., 2005. Time constraints for Mesoproterozoic upper amphibolites facies metamorphism in NW Namibia: a multi-isotopic approach. Earth and Planetary Science Letters 230,355-378.

Siga Jr., O., Cury, L.F., McReath, I., Leite Ribeiro, L.M., Sato, K., Basei, M.A.S., Passarelli, C.R. 2011. Geology and geochronology of the Betara region in south-southeastern Brazil: evidence for possible Statherian (1.80-1.75 Ga) and Calymmian (1.50-1.45 Ga) extension events. Gondwana Research 19, 260-274

Tohver, E., Cawood, P.A., Rosello, E.A., Jourdan, F., 2011. Closure of the Clymene Ocean and formation of West Gondwana in the Cambrian: evidence from the Sierras Australes of the southernmost Río de la Plata craton. Argentina. Gondwana Research. doi: $10.1016 /$ j.gr.2011.04.001

Van Staden, A., Zimmermann, U., Chemale Jr., F., Gutzmer, J., Germs, G.J.B., 2010 Correlation of Ordovician diamictites from Argentina and South Africa using detrital zircon dating. Journal of the Geological Society, London 167, 217-220.

Verdecchia, S.O., Casquet, C., Baldo, E.G., Pankhurst, R.J., Rapela, C.W., Fanning, C.M. Galindo, C, 2011. Mid- to late Cambrian Docking of the Río de la Plata craton to southwestern Gondwana: age constraints from U-Pb SHRIMP detrital zircon ages from Sierras de Ambato and Velasco (Sierras Pampeanas, Argentina). Journal of the Geological Society, London 168, 1061-1071.

Vervoort, J.D., Blichert-Toft, J., 1999. Evolution of the depleted mantle: Hf isotope evidence from juvenile rocks through time. Geochimica et Cosmochimica Acta 63 533-556.

Vinyu, M.L.,Hanson, R.E., Martin, M.W.,Bowring, S.A.,Jelsma, H.E., Krol,M.A., Dirks, P.H.G.M. 1999. U-Pband ${ }^{40} \mathrm{Ar} /{ }^{39} \mathrm{Ar}$ geochronological constraints on the tectonic evolution of the easternmost part of the Zambezi orogenic belt. northeast Zimbabwe. Precambrian Research 98, 67-82.

Warren, R.G.,Ellis, D.J., 1996. Mantle underplating, granite tectonics, and metamorphic P-T-t paths. Geology 24, 663-666

Williams, I.S., 1998. U-Th-Pb geochronology by ion microprobe. In: McKibben, M.A ShanksIII III, W.C. Ridley, W.I. (Eds.), Applications of Microanalytical Techniques to Understanding Mineralizing Processes: Reviews of Economic Geology, 7, pp. 1-35.

Zimmermann, U., Spalletti, L.A., 2009. Provenance of the lower paleozoic balcarce formation (Tandilia System, Buenos Aires Province, Argentina): implications for paleogeographic reconstructions of SW Gondwana. Sediment. Geol. 219, $7-23$.

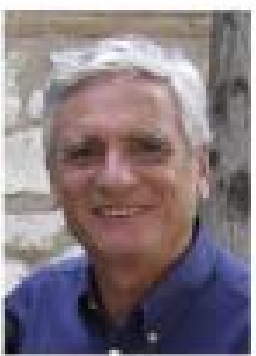

Carlos Washington Rapela has been a Professor in Advance Geochemistry at the Universidad Nacional de La Plata (UNLP, Argentina) since 1986 , a Career Investigator of the National Research Council of Argentina (CONICET) since 1979, Director of the Centre of Scientific and Technological Research (CONICEI-Ia Plata) since 2009 and is a Member of the National Academies of Sciences (Córdoba and Buenos Aires). He obtained a degree in Geochemistry and a PhD in Natural Sciences from UNLP in 1970 and 1975, respectively, and then worked as a Post-doctoral Fellow at McMaster University, Canada, from 1977 to 1979 . His interests are in the geochemistry and isotope geology of magmas, geochronology and tectonics. He has edited books for the Geological Society of America and the Geological Society, London, and has authored or co-authored more than 130 articles in specialist journals. He was the joint leader of two IGCP projects of the International Union of Geological Sciences and UNESCO, both focused on Andean geology. He has served as a member of the IGCPBoard in Paris (1995-1999), Director of the Centro de Investigaciones Geológicas (CONICET-UNLP, 2003-2009) and a member of the executive board of CONICEI (2003-2008). He has received many named prizes and awardsfor his contributions togeology: Storni (GeologicalAssociation of Argentina, 1976), Bernardo Houssay (CONICEI, 1987), Strobel (Universidad de Buenos Aires, 2001), KONEX (2003), Houssay (2004, SECYT), Geological Association of Argentina (AGA 2007).

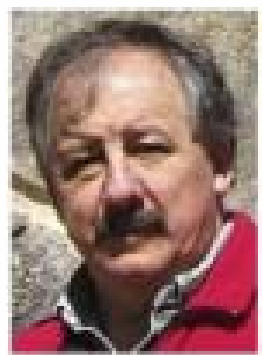

C. Marlc Fanning is a Senior Fellow at the Research School of Earth Scienoes, The Australian National University, Canberra, Auswalia $\mathrm{He}$ is the Manager of Prise, a research group that provides external access to the Research School's equipment and expertise in the areas of isotope geochemistry and geochronology. He is a graduate of the University of Adelaide (BSc HONS 1975). He is a Fellow of the Geological Society of America and hasover 30 years experience in radiogenic isotope systems, predominantlyU-Pb on zircons. More recently he has been involved with oxygen isotope analyses of $\mathrm{U}-\mathrm{Pb}$ dated zircons (SHRIMP), coupled with LA MC ICPMS Lu-Hf isotopic analyses. His interests are in the application of these microbeam techniques to the solution of geological problems, in particular tracing the source of magmatic rocks and identifying possible sediment souroes Recent oollaborations have led to field work in the Transantarctic Mountains, Antarctica Peninsula, Sierras Pampeanas, Patagonia, Tierra del Fuego and œentral Chile. He has been involved in the publication of numerous papers and a number of book chapters.

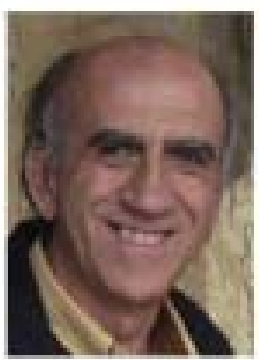

Cesar Casquet is a Professor in the Faculty of Geology at Universidad Complutense in Madrid, Spain, where he received the title of Doctor of Geology in 1980 . He has focused on diverse issues in metamorphic and igneous petrology, as well as geochronology and isotope geology, in several regions of the Iberian Peninsula and South America, particularly in the Argentine pre-Andean basement since 1993. He has also devoted work to ore petrology processes, particularly to hydrothermal replacements and their structural controls, geochronology, the source of metals, and fluid-rock interaction. He is an Associate Editor of both the Joumal of South America Earth Sciences and Andean Geology and member of the editorial boards of the Journal of Iberian Geology and Revista de la Sociedad Geológica de España He has collaborated with geoscientists in Spain, Argentina, UK, Chile, Brazil and Australia and has been the leader of several large scale publicly-funded research projects. He has been involved as author and editor in numerous published papers and several special publications.

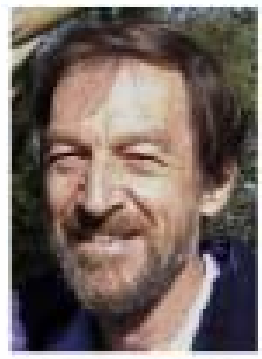

Robert (Bob) Panlchurst is a Visiting Research Associate at the British Geological Survey, having worked for 26 years in the NERC Isotope Geosciences Laboratory carrying out geochronological and isotope research on behalf of the British Antarctic Survey (BAS). He has undertaken extensive fieldwork in West Antarctica and southern South America concentrating on the latter since official retirement in 2002 He holds the Polar Medal (1987) and is a Corresponding Member of both Chilean and Argentine Academies of Science, and of the Argentine Geological Association. He is the Chie Books Editor for the Geological Society, London, and Associate Editor for the Joumal of South American Earth Sciences. He graduated from the University of Cambridge (B.A. 1964, M.A. 1967) where he also holds the title of Doctor of Science (Sc.D. 1998). He received a Diploma in Geochemistry (1965) and a D.Phil (1968) from the University of Oxford, staying as Research Fellow on projects in Scotland, West Greenland and Ioeland before joining BAS in 1976. His main interests are in isotope dating and geochemistry applied to igneous petrogenesis, metamorphism and sediment provenance in relation to the tectonic evolution of West Gondwana. He has activelycollaborated with geoscientists in Argentina, Australia, Brazil, Chile, New Zealand, Spain, and the USA, and has been involved in numerous published papers and several books. 


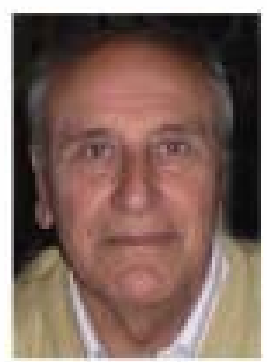

Luis Antonio Spalletti is a Professor of Sedimentology a the Universidad Nacional de La Plata (UNLP, Argentina) and Superior Researcher of the National Research Council of Argentina (CONICET), based at the Centro de Investigaciones Geológicas (UNLP-CONICET). He obtained his degree in Geology (1966) and his $\mathrm{PhD}(1971)$ at UNLP. He is Member of the National Academy of Sciences of Argentina (since 2001). He has published over 190 articles in peer-reviewed scientific literature, and has acted as editor and co-editor of 10 thematic books and special issues of journals. Among several awards, Dr. Spalletti was nominated as an Honorary Member of the Asociación Argentina de Sedimentología (2000), Honorary Member of the International Association of Sedimentologists (2001), and Honorary Chairman of the 18th International Sedimentological Congress (2010). His research interest primarily involves the sedimentology and stratigraphy of siliciclastic and mixed (carbonate/siliciclastic) successions. At present, his work focuses mainly on sequence stratigraphy and sedimentology of the Jurassic and Cretaceous deposits of the Neuquén Basin of Argentina.

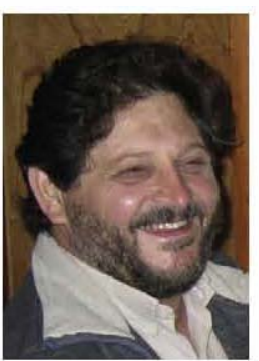

Edgardo G. A. Baldo is a Full Professor of Introduction to Geology at the Universidad Nacional de Córdoba, Argentina (UNC, 1980-present), a Career Investigator of the National Research Council of Argentina (CONICET, 1994 present), Director of PhD Graduate Studies in Geological Sciences at UNC (2009-present). He obtained a degree in Geology (1982) and PhD in Geological Sciences (1992) at UNC. His main interests are in metamorphic petrology, geochronology and tectonics of the Sierras Pampeanas, Argentina. He has co-authored over 50 articles in scientific journals.

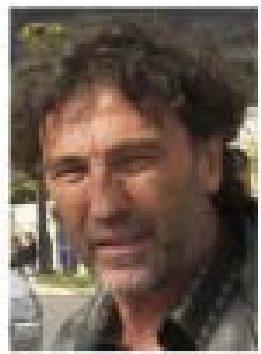

Daniel Gustavo Poiré is a Full Prof essor of the Universidad Nacional de La Plata (UNLP) and Career Researcher of the National Research Council of Argentina (CONICET), and works at the Centro de Investigaciones Geológicas (UNLPCONICET). He was born in La Plata, where he took a degree in Geology in 1979 and obtained a PhD in Natural Sciences (Geology, UNLP) in 1987. He moved to the University of Liverpool, UK for postdoctoral experience before returning to La Plata. He was the first Chief Editor of the Latin American Journal of Sedimentology and Basin Analysis (LAJSBA) for the Argentine Association of Sedimentology. His main interests are modern and ancient organic sedimentary structures (trace fossils, stromatolites and microbial mats). He has actively collaborated with geologists and microbiologists in Argentina, Uruguay, Brazil, Bolivia, England, Wales, South Africa and USA, and has been involved in numerous published papers and several books. He has given postgraduate courses on the sedimentological significance of trace fossils and stromatolites in Argentine universities and in the University of Barcelona, Spain. 